\title{
Chimeric antigen receptor (CAR) immunotherapy: basic principles, current advances, and future prospects in neuro-oncology
}

\author{
Hyeon Joo Yoo ${ }^{1}$ (D) Biyan Nathanael Harapan²
}

Received: 22 February 2021 / Accepted: 31 August 2021

(c) The Author(s) 2021

\begin{abstract}
With recent advances, chimeric antigen receptor (CAR) immunotherapy has become a promising modality for patients with refractory cancer diseases. The successful results of CAR T cell therapy in relapsed and refractory B-cell malignancies shifted the paradigm of cancer immunotherapy by awakening the scientific, clinical, and commercial interest in translating this technology for the treatment of solid cancers. This review elaborates on fundamental principles of CAR T cell therapy (development of CAR construct, challenges of CAR T cell therapy) and its application on solid tumors as well as CAR T cell therapy potential in the field of neuro-oncology. Glioblastoma (GBM) is identified as one of the most challenging solid tumors with a permissive immunological milieu and dismal prognosis. Standard multimodal treatment using maximal safe resection, radiochemotherapy, and maintenance chemotherapy extends the overall survival beyond a year. Recurrence is, however, inevitable. GBM holds several unique features including its vast intratumoral heterogeneity, immunosuppressive environment, and a partially permissive anatomic blood-brain barrier, which offers a unique opportunity to investigate new treatment approaches. Tremendous efforts have been made in recent years to investigate novel CAR targets and target combinations with standard modalities for solid tumors and GBM to improve treatment efficacy. In this review, we outline the history of CAR immunotherapy development, relevant CAR target antigens validated with CAR T cells as well as preclinical approaches in combination with adjunct approaches via checkpoint inhibition, bispecific antibodies, and second-line systemic therapies that enhance anticancer efficacy of the CAR-based cancer immunotherapy.
\end{abstract}

Keywords Chimeric antigen receptor $\cdot \mathrm{CAR} \cdot \mathrm{T}$ cells $\cdot$ Immunotherapy $\cdot$ Adoptive cell therapy $\cdot$ Neuro-oncology

\section{The rise of immuno-oncology}

In the 1980 s, a new chapter of cellular immunotherapy was established for cancer patients, as the initial successful clinical applications of adoptive cell transfer in patients with metastatic melanoma and relapsed leukemia revealed the potential of a therapeutic approach with tumor-specific T cells [1-4]. Gene transfer techniques and the focus on selecting and expanding naturally occurring $\mathrm{T}$ cells found in patients or healthy

Biyan Nathanael Harapan

biyan.harapan@gmail.com;

biyan.harapan@med.uni-muenchen.de

1 Department of Internal Medicine V, Heidelberg University Hospital, 69120 Heidelberg, Germany

2 Department of Neurosurgery, University Hospital, Ludwig-Maximilians-University of Munich, 81377 Munich, Germany donors were shared features of late twentieth century approaches [5]. Adoptive cell therapy (ACT) with tumor-infiltrating lymphocytes (TILs), T cell receptor (TCR)-modified T cells, and chimeric antigen receptor (CAR) $\mathrm{T}$ cells represent pioneer strategies. Nevertheless, TIL-based therapy showed major limitations as the process to harness TILs incited crucial challenges in logistical manner, whilst achieving limited results in selected highly immunogenic cancer entities (e.g. malignant melanoma) in terms of patient-specific treatment [6-8]. As an alternative to TIL-based therapy, T cell receptor (TCR) was genetically engineered to confer the specificity to a particular tumor target. Depending on the expression of human leukocyte antigen (HLA), T cells are generally restricted in their antigen recognition, which leads to limitations concerning application of TCR-modified T cells. Of note, tumors escape from immune surveillance of endogenous $\mathrm{T}$-cell repertoire through downregulation 
of HLA-expression [9]. Genetic modification of autologous $\mathrm{T}$ cells by introduction of TCRs using either viral-mediated transduction of retrovirus [10-12], lentivirus [13-16], or nonviral gene transfer of DNA plasmids [17-31] or in vitro-transcribed mRNA species [32,33], aptly named "chimeric antigen receptor" transgene, combines the functional dynamics of T cells with the antigen-specificity of an antibody to augment $\mathrm{T}$ cell function $[5,34,35]$. After infusion, CAR T cells may stimulate immune surveillance to prevent tumor recurrence through trans- as well as auto-costimulation and thus responding to tumor cells lacking costimulatory ligands $[36,37]$. Since our immune system is programmed to avoid autoreactive immune responses [38], antitumor responses are frequently transient and ineffective as most tumor antigens are self-antigens that are also present in normal tissues [39], and host immune responses are evolved to prevent autoimmunity [40]. This aspect represents the main challenge in immunooncology, while CAR technology in the sense of T cell engineering provides a mean to overcome immune tolerance. The direct binding of CAR to antigen induces a competent activation signal, proliferation, and cytokine production independent of major histocompatibility complex (MHC) with extended applicability to multiple types of cancer [41-43].

\section{Development of CAR construct}

Chimeric antigen receptors (CARs) are synthetic receptors which recognize and target cells expressing a cognate target ligand and as a result redirect the killing activity of CAR T cells against a specific tumor cell antigen [44]. CAR constructs consist of four main components: the single-chain variable fragment $(\mathrm{scFv})$, the hinge, the transmembrane (TM) domain, and the intracellular signaling domain [45] (Fig. 1A). The CAR concept was originally reported by a Japanese group in 1987 [46] and further studied and developed at the Weizmann Institute by Zelig Eshhar, thereby establishing the first generation CARs [47, 48]. The potency of CAR signaling was subsequently improved by addition of costimulatory domains by Michel Sadelain, from whom the second, third, and fourth generation CARs were developed $[35,49,50]$ (Fig. 1B). By identifying and evaluating the critical role of 4-1BB (CD 137) costimulation, Carl June's group essentially contributed to expand the knowledge on second and third generation CARs [51-55].

Each of the four components has a distinct function and has been optimized through many variations of the constituent protein domains to maximize tumor detection, $\mathrm{T}$ cell activation, and tumor elimination [56].

The specificity of a CAR is conferred by its ectodomain derived from the antigen binding of a monoclonal antibody a

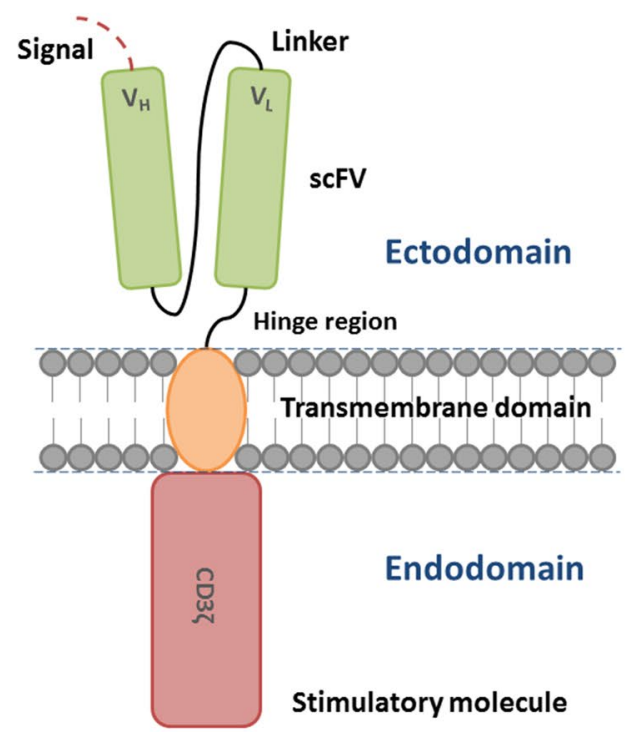

b

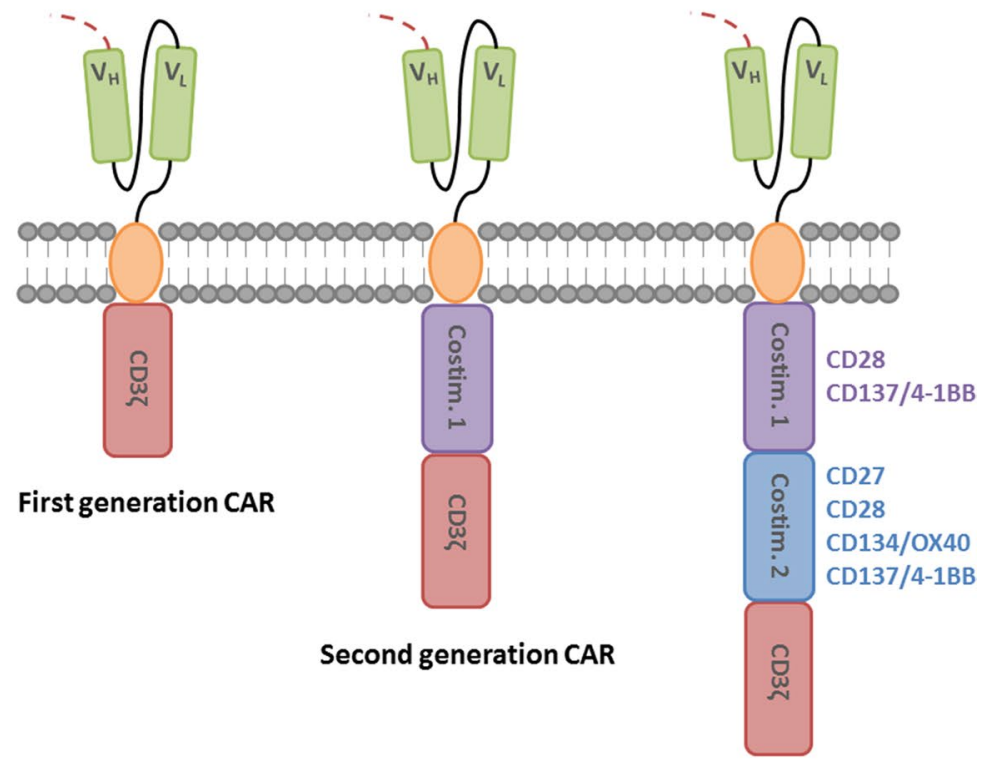

Third generation CAR
Fig. 1 A Chimeric antigen receptor (CAR). CARs consist of four main components: the single-chain fragment variant ( $\mathrm{scFv}$ ), an extracellular spacer domain (hinge region), a transmembrane domain, and an intracellular signaling domain (stimulatory molecule: $\mathrm{CD} 3 \zeta$ ). $\mathrm{V}_{\mathrm{H}}$, heavy chain variable region. $\mathrm{V}_{\mathrm{L}}$, light chain variable region. B Evo- lution of chimeric antigen receptor (CAR). According to the evolution of CARs, the sophistication of the receptor has grown over time. They are referred to as the first, second, and third CARs, depending on the structure of their intracellular T cell region. Costim., costimulatory domain/element 
$(\mathrm{mAb})$ with a heavy $\left(V_{H}\right)$ and light $\left(V_{L}\right)$ variable fragment connected by a flexible linker to construct a single-chain fragment variable ( $\mathrm{scFv}$ ) region for HLA-independent antigen recognition [46]. The order of variable fragments and the length of the linker have an impact on the antigen-binding affinity and the stability of the construct $[57,58]$. The length and composition of the spacer domain determine the optimal distance between effector and target cell and are essential for immunological synapse formation $[59,60]$ and additional stability [61] by influencing CAR T cell function independent from the intracellular domain [62]. The spacer domain is commonly composed of amino acid sequences from CD28 or CD8 $\alpha$ as well as $\mathrm{CH} 2$ and $\mathrm{CD} 3$ domains from IgG1, 2, or 4 [45, 57, 63].

The transmembrane domain consists of a hydrophobic alpha helix, which anchors the CAR construct. The TM region affects the degree of cell activation, hence, the functionality of CAR. CD28-derived TM domains are more prone to trigger activation-induced cell death (AICD) in T cells, whilst a CD3 $\zeta$-derived ones facilitate CAR dimerization with endogenous TCRs, thereby inducing T cell activation [64, 65].

The CAR design has been developed over generations. Its evolution has primarily focused on optimizing the intracellular signaling domains. The first-generation CARs only contained an activating domain, namely, $\mathrm{CD} 3 \zeta$, without a costimulatory domain. They showed limited cytokine production, insufficient $\mathrm{T}$ cell proliferation, and expansion, and rapidly became anergic [35, 45, 66, 67]. The clinical application of the $\mathrm{CD} 3 \zeta$-based CAR T cells in patients suffering from ovarian cancer [68], neuroblastoma [69], and non-Hodgkin's lymphoma (NHL) [18] revealed limitations. The second and third generation CARs contain one or two costimulatory domains, respectively [70, 71], which enhance proliferation and exhibit antiapoptotic functions in human primary T cells [72] by directing the expansion of functional $\mathrm{T}$ cells on repeated exposure to antigen [49]. The second generation CARs achieved long-term persistence, expansion, and protection from AICD through integration of a costimulatory domain such as CD27 [73], CD28 [74, 75], CD134 (OX40) [76], or CD137 (CD4-1BB) [77, 78]. By combining the advantageous aspects of costimulatory domains, the third generation CARs emerged with greater intracellular signaling activity as well as superior persistence and proliferation properties [79, 80]. Kinetic and quantitative differences in CARs with different signaling domains have been demonstrated, highlighting that the choice of costimulatory signal has proven to be a critical element of CAR design [81].

\section{CAR T cell therapy}

Adoptive transfer of autologous CD19-targeted CAR T cells was approved by the US Food and Drug Administration (FDA) as the first therapeutic approach with a genetic engineering component $[82,83]$ due to remarkable response rates, particularly in patients with diffuse large B cell lymphoma (DLBCL) or acute lymphoblastic leukemia (ALL) [84-90]. The first protocols either used gamma-retroviral or lentiviral vectors including either CD28- or 4-1BB-containing constructs $[73,82,83,91,92]$. Additional tumor antigen targets such as B cell maturation antigen (BCMA, also known as CD269) for treatment of multiple myeloma [93] have recently been discovered and are currently being evaluated. Further clinical approaches confirmed the data in larger series [5, 85, 86, 94].

In comparison to CD20 or CD22, CD19 is most commonly chosen as a target antigen $[95,96]$ due to its frequent, broader, and greater expression in B-cell leukemia and lymphoma in relation to other potential targets.

The manufacturing time, financial burden, and severe toxicities associated with CAR T cell therapy represent current limitations [97]. Generation of an autologous CAR T cell product from chemorefractive patients is particularly limited in the quality of the obtained T cells as well as in the survival time of the patients (Fig. 2). The patients are required to be treatment-free for 2 weeks prior to apheresis to ensure sufficient cell numbers and qualitative viability for the manufacturing process, which takes around 2-4 weeks [88]. The alternative treatment with allogeneic CAR T cell products carries the critical risk of graft-versus-host-disease (GvHD), a life-threatening condition with rapid elimination of CAR T cells by the host immune system [98].

The spectrum of adverse effects associated with CAR $T$ cells includes on-target effects, depending on the specificity of antibody $\mathrm{scFv}$ and $\mathrm{T}$ cell activation. These toxic effects are reversible once the target cells are eliminated, or the CAR T engraftment is terminated. In contrast, offtarget toxic effects can be promoted by transduced T-cell population that undergo antigen-independent activation or unexpectedly attacks an antigen other than the intended one, possibly causing significant clinical long-term consequences, e.g., cardiac toxicity $[99,100]$. This phenomenon is unrelated to toxicity due to other lines of treatment. To minimize the risk of off-target activation, the spacer domain of CARs can be modified, thereby avoiding an unintended initiation of an innate immune response [101].

Another potential side effect that poses a limitation of CAR technology is on-target/off-tumor toxicity, which occurs when CAR T cells attack nonpathogenic tissue that express the target antigen and therefore react with antigen different from the one intended. This is largely due to the fact that many targets of CAR T cells are also expressed on normal, non-tumor cells, leading to on-target/off-tumor toxicity to some extent through engagement of target antigen on nonpathogenic tissues [100,102].

CAR T cell therapy can cause a clinical syndrome termed "cytokine release syndrome" (CRS) consisting of high fever, 
Fig. 2 Manufacture of chimeric antigen receptor (CAR) $\mathrm{T}$ cells. Primarily, autologous T cells are isolated through leukapheresis and genetically modified ex vivo to express CARs, followed by the expansion in culture. After gene transfer of a CAR vector, the CAR T cells are expanded. Magnetic bead-based artificial antigen-presenting cells, which were used to activate $\mathrm{T}$ cells, are subsequently removed from the culture to isolate CAR T cells. The final CAR T cell culture is washed, concentrated, and subjected to end-of-process formulation with quality control testing and cryopreservation. Patients usually receive a lymphodepletion prior to the ultimate CAR T cell administration
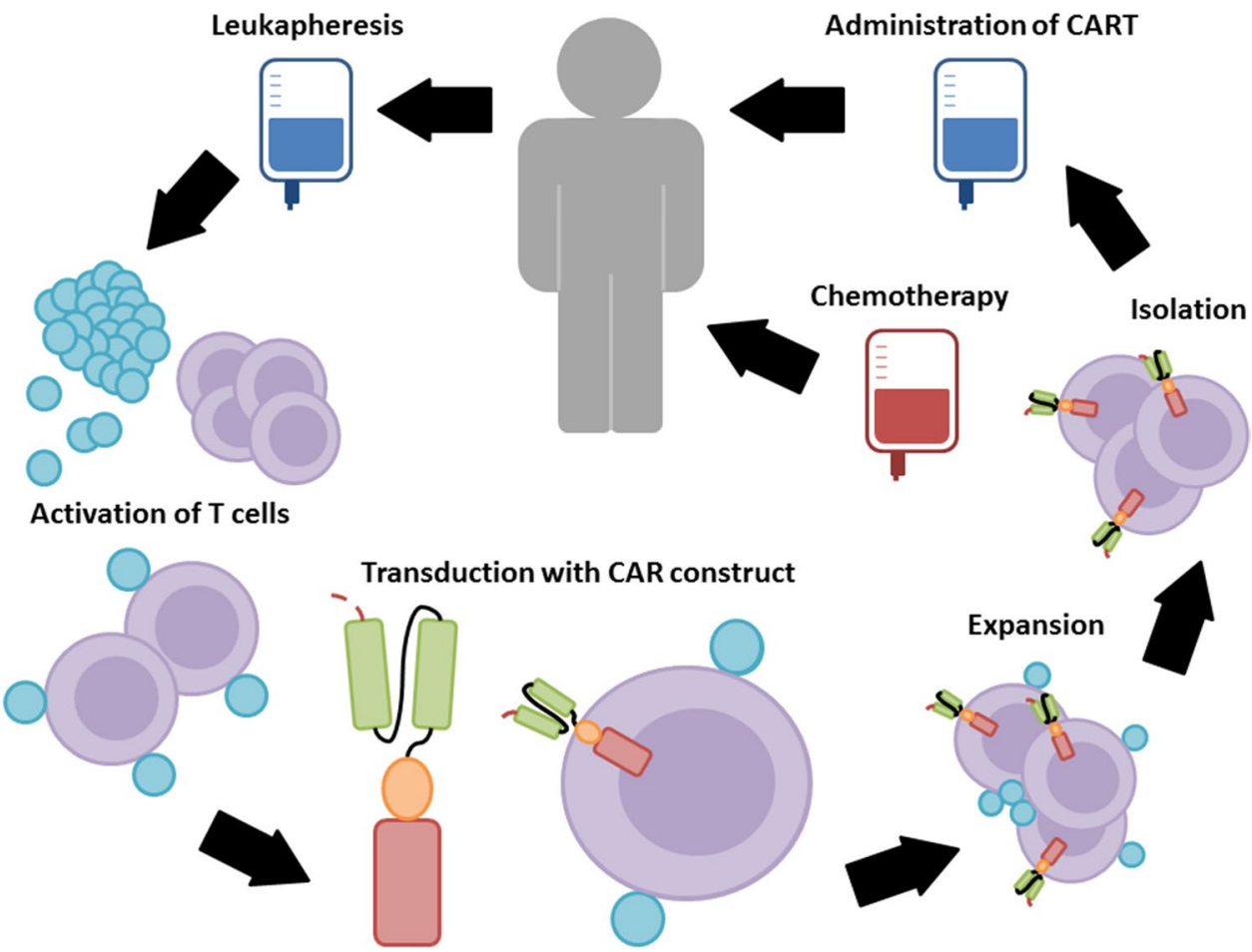

hypotension, hypoxia, tachycardia, and neurologic symptoms and complications associated with elevated levels of serum cytokines [85, 86, 103-105]. This syndrome seems to be related to both CD19 and BCMA CARs, while the severity correlates with tumor burden as measured by blasts in bone marrow at the time of therapy [106-108]. On-target CAR T cell activation leads to massive proliferation as well as release of high levels of cytokines and chemokines such as IL-6, IFN- $\gamma$, GM-CSF, and soluble IL-6R and IL-2R $\alpha$. Tocilizumab (Actemra), an IL-6-receptor antagonist, is an effective antibody recently approved by the FDA for the treatment of severe cytokine release syndrome caused by CAR T cells. It may lead to rapid resolution of severe CRS after blockade of IL-6R [90, 107]. As an alternative, glucocorticoid can be administered if patients do not respond well to IL-6R blockade [84, 85, 89, 107, 109, 110].

Neurotoxicity, immune effector cell-associated neurologic syndrome (ICANS), has been observed to develop after CRS and appears to be an adverse effect related to, among others, CD19-directed therapies [111, 112] since a similar spectrum of toxic effects have been observed with blinatumomab, which is a bispecific anti-CD19 and antiCD3 monoclonal antibody [113]. The symptoms range from encephalopathy to expressive aphasia and seizures [86, 114, 115]. Even though the cause remains largely unknown, they are usually reversible and not associated with the spread of cancer to the central nervous system (CNS). Rare cases of cerebral edema have been reported in some trials $[114,115]$. Until the pathophysiology of the neurologic syndrome is fully explained, the ultimate management remains primarily empirical and has mainly been directed towards management of CRS by suppression of $\mathrm{T}$ cell activation with corticosteroids and symptomatic and supportive care to maintain organ function [115].

Multi-antigen-targeted CAR T cells provide a strategy to expand the CAR T cell therapeutic window and overcome limitations by antigen escape and on-target/off-tumor toxicities by simultaneously targeting multiple surface antigens [116]. For instance, OR-gate CARs provide two scFv domains against various targets, which are either bound to a single TM and intracellular domain ("tandem CAR") or represent two complete CAR constructs expressed on the same cell ("dual CAR"), aiming to prevent tumor escape [117-119]. AND-gate CARs also feature two scFvs, however, they require both antigens on the same cell prior to the ultimate signal propagation, from which tumor specificity is achieved by the dual expression of both antigens ("combinatorial CAR") [120-122]. Other components of the immune system can be recruited and activated via additional expression of costimulatory ligands, such as 4-1BB-L [123] and CD40-L [124] or proinflammatory cytokines. The structure of On-Switch CARs relies on a small molecule, which assembles the fragmented CAR construct to allow a controlled CAR activation through the administration of a drug, thereby allowing titrable pharmacologic regulation [125]. Universal CARs describe another type of fragmented CAR design, in which the antigen-specific region can be exchanged to facilitate the targeting of different cancer types 
through the same TM and intracellular signaling construct [126-129].

In addition to second and third generation CARs, the fourth generation of CAR construct was developed to shape the tumor environment by the inducible release of immune modifiers [130, 131]. Sometimes, also referred to as $\mathrm{T}$ cells redirected for universal cytokine-mediated killing ("TRUCKs"), the fourth generation of CAR T cells is a novel design for targeting solid tumors and carry a transgenic "payload." They are armed with immune stimulatory cytokines [131], which consequently improve CAR T cell expansion and persistence with increased resistance towards immunosuppressive tumor microenvironment (TME) [132]. As transgenic cytokine expression potentially triggers bystander $\mathrm{T}$ cells, antigen-negative cancer cells at the target site can be eliminated. The cytokines studied to date include IL-7, IL-12 [133, 134], IL-15 [135], IL-18 [136, 137], and IL-21 [138]. As IL-15 supports the development of T-memory stem cells $\left(\mathrm{T}_{\mathrm{scm}}\right)$ that promote superior in vivo function and persistence without influencing regulatory $\mathrm{T}\left(\mathrm{T}_{\mathrm{reg}}\right)$ cells, it was observed to have a great potential to improve the function of CAR T cells [139-141]. Moreover, tumor-targeted IL-12 secreting T cells were shown to become resistant against inhibitory signals mediated by $\mathrm{T}_{\text {reg }}$ cells [134], resulting in maintenance of the optimal therapeutic level and accumulation of cytokines in target tissues, and thus, in destruction of both TAA (tumor-associated antigens)-expressing and TAA-negative tumor cells [142, 143]. To adapt this approach in terms of a protocol in practical manner, exact toxicity profile with controlled release of cytokines for safe application of this strategy must be guaranteed [144]. Inhibitory CARs turn an immunosuppressive signal from a tumor cell into an activating signal by fusing the extracellular inhibitory domain, for instance, PD-1, to activate intracellular CAR domain [145]. To optimize safety profile of CAR T cells, a suicide gene switch can be triggered in the event of adverse effects [146].

Moreover, an alternative strategy to mitigate the limitations of CAR T cell therapy has been developed, in which natural killer (NK) cells are utilized instead of T cells. As target recognition mechanisms of NK cells differ from that of cytotoxic T-lymphocytes (CTLs), NK cells, as innate lymphoid cells, receive activating and inhibitory signals by their germline-encoded receptor repertoire with the ability to recognize the absence of HLA-proteins. Thus, CAR T cells and CAR NK cells differ in various attributes. CAR T cells may be more effective in killing tumors and are more persistent in vivo, whereas CAR NK cells may offer a more favorable safety profile by combining natural anti-tumor function of NK cells with CAR-redirected function in terms of an intrinsic killing capacity of malignant cells with only a few side effects post-transplantation, such as limited CRS risks. However, they do not last as long and tend to require repeated administrations. Most CAR T cell-based approaches consist of autologous enriched T cells, whereas CAR NK cell-based gene therapy products can be generated from allogeneic donors, so that they possibly reduce the tremendous costs and the limited availability of an autologous therapy caused by logistics and the low cell numbers of heavily pretreated patients [147-149].

\section{Solid tumors}

Modern attempts have recently been made to strive for successful treatment for solid tumors. Since these tumor entities rarely express specific target antigens, tumor-associated antigens that are enriched on most solid tumors are aimed as targets. The antigens studied so far include CEA, ERBB2, EGFR, GD2, CD33, CD123, mesothelin, MUC1, PSMA, PSCA, STn, and others [150-155]. However, since they are also expressed at low levels in normal tissues, the potential risk of significant on-target/off-tumor toxicity is increased [156-160].

The main challenges when targeting solid tumors are generally associated with the complicated structure and cellular milieu of solid tumors, which leads to inefficient penetration of CAR T cells into tumors [161, 162]. Even in the setting of a uniformly expressed TAA, there is still a great possibility of antigen loss or antigen escape when target antigen disappears from the surviving tumor [135, 159, 163-165], or the highly immunosuppressive nature of TME overcome CAR $\mathrm{T}$ cell activation and persistence [166].

Antigen heterogeneity poses a major obstacle to the use of CAR T cells for treatment of solid malignancies. The term refers to the different cells of the same tumor expressing different antigens. Thus, if only one antigen is targeted by CAR T cells, tumor cells negative for that specific antigen will escape [167].

CAR T cell-mediated lysis can further release tumorspecific neoantigens or epitopes that might be processed and presented by APCs to TILs, resulting in a secondary immune response that bolsters the efficacy of CAR T cells against tumor entities such as melanoma [168], NSCLC [169], malignant pleural mesotheliomas [170], pancreatic cancers [171], and others.

Several strategies and mechanisms have been under development to deal with and overcome the antigen heterogeneity of solid tumors, including the aforementioned fourth generation CARs with different construct designs. Anti-EGFR BiTEs were observed to increase the efficacy of antifolate receptor- $\alpha$ CAR $T$ cells in preclinical models of the ovarian, colon, or pancreatic cancer and of anti-EGFRvIII CAR $\mathrm{T}$ cells in mouse models of GBM, providing the rationale to test this therapy in human trials with patients with solid tumors [172, 173]. Notably, universal CARs have been 
created, for which adapter elements are required as ligands to enable the targeting of multiple antigens with a single CAR T cell population. Different strategies play a significant role to successfully target heterogeneous solid tumors whilst minimizing possible off-tumor toxicities.

Numerous engineering strategies have already been implemented to improve and enhance CAR T cell trafficking in solid tumors. To avoid the challenges and adverse effects that arise from systemic application, CAR T cells have been injected directly intratumorally, among others in brain tumors [174], breast cancer [175], pleura mesothelioma [170], and liver metastases [176]. This approach has shown promising responses with the potential to limit on-target/offtumor toxicities [177]. The regional application allows CAR $\mathrm{T}$ cells to expand and traffic to other tumor sites and promote responses of endogenous immune effect against tumors. An antitumor humoral response with multiple additional antigens has also been observed in patients who received infusions of $\mathrm{T}$ cells transduced with mRNA encoding an antimesothelin CAR [170]. Although it has not yet been studied extensively, this result suggests the potential application of regional delivery of CAR T cells to initiate systemic anticancer immune responses. Since many metastatic solid tumors are not susceptible to localized therapy, efforts to engineer CAR T cells with an intrinsic ability to optimize trafficking to sites of disease are of utmost importance.

Chemokines are crucial factors that mediate immune cell trafficking [178]. Expression of the macrophage colonystimulating factor 1 receptor (CSF-1R) in CAR T cells would promote the cells to become responsive to CSF-1, which is enriched in many solid tumors. Similarly, CCR2b, which is the receptor for CCL2, seems overexpressed in multiple types of solid tumors, enhancing the infiltration of anti-GD2 CAR T cells into neuroblastoma xenograft tumors [179] as well as anti-mesothelin CAR T cell infiltration into mesothelioma xenografts by more than 12.5 -fold with increased antitumor efficacy [180]. Expression of CC-chemokine receptor 4 (CCR4), which is commonly expressed on $\mathrm{T}$ helper $\left(\mathrm{T}_{\mathrm{h}}\right)$ cells and $\mathrm{T}_{\text {reg }}$ cells, is typically activated via CC-chemokine ligand 17 (CCL17) and CCL22 secreted by Reed-Sternberg cells of Hodgkin lymphoma, enhancing both CAR T cell migration to tumors and antitumor efficacy in a mouse xenograft model of Hodgkin lymphoma [181].

Inhibition of the PD-1 pathway causes an essential clinical benefit in patients with certain types of cancer [182]. PD-1 is an immune-checkpoint receptor expressed on activated $\mathrm{T}$ cells and can bind to PD-L1 expressed by tumor cells as well as other cell types to adopt an exhausted phenotype. CAR T cells engineered to secrete antagonistic antiPD-1 scFvs showed a synergistic improvement in functionality and prolonged survival in immunocompetent syngeneic mouse models of PD-L1-positive hematological or solid cancers [183] as well as in xenograft [183, 184]. Increased anticancer efficacy of CAR T cell therapy via coadministration of antibodies inhibiting the PD-1 pathway in preclinical models [185] and in patients with ALL or DLBCL has been shown $[186,187]$. Successful strategies regarding combination of CAR T cells with established immune-checkpoint inhibitors or other prodrugs have been demonstrated thus far. For instance, increased levels of reactive oxygen species (ROS) in TME are exploited by using ROS accelerator named as $\mathrm{PipFcB}$, which is specifically activated in cancer cells to induce further generation and accumulation of ROS, due to which the tumor cells are rather primed to undergo lysis than other surrounding normal cells [188]. Besides anti-PD-1 scFv-secretion, CAR T cells are able to counter the actions of adenosine in the TME, which activates adenosine receptor $\mathrm{A}_{2 \mathrm{~A}}$ to inhibit $\mathrm{T}$ cell function $[189,190]$. Inhibitory signals in the TME also represent a challenging problem for CAR T cells which needs to be resolved. CAR T cells have been engineered to express switch cytokine receptors which convert inhibitory signals present in the TME into proinflammatory signals $[172,191,192]$ or dominant-negative TGF $\beta$-receptors that increase the ability to infiltrate, proliferate and enhance cytokine secretion, resist exhaustion and induce tumor eradication [193].

Amino acids, oxygen, and other nutrients in the TME influence the metabolism, function, and differentiation of T cells [194, 195]. Rapidly proliferating cancer cells and T effector cells have a strong demand for amino acids. Arginine, for instance, plays an important role for $\mathrm{T}$ cell function. Consequently, the competition between cancer and $\mathrm{T}$ effector cells over arginine in the TME might result in suppression of antitumor activity of $\mathrm{T}$ cells, possibly leading to $\mathrm{T}$ cell anergy. Therefore, supplementing T cells with arginine can improve the survival capacity and antitumor activity of these cells [196]. Engineering T cell metabolic pathways to express the antioxidant enzyme catalase enables $\mathrm{T}$ cells to better resist oxidative stress in vitro [197].

Since antigen escape remains a major concern in CAR $\mathrm{T}$ cell therapy, recruitment and activation of endogenous immune cells can be necessary to propagate and modulate an efficient antitumor immune response. For instance, TRUCKs can increase activity of CAR T cells that secrete stimulatory cytokines to trigger proliferation as well as to enhance survival and antitumor efficacy, while simultaneously altering the immune milieu of solid tumors [130].

\section{CAR T cell therapy in neuro-oncology}

In recent years, several CARs for GBM have been developed and tested in clinical trials (Table 1). Some results seem to be quite promising. As the most common and malignant primary brain tumor in adults, GBM is responsible for $3-4 \%$ of all cancer-related deaths with an extremely poor prognosis 
Table 1 Completed clinical trials of CAR T cell therapy in patients with GBM

\begin{tabular}{|c|c|c|c|c|c|}
\hline Target antigen & Reference & Study phase & Dosage of CAR T cells & Response & Clinical trial \\
\hline \multirow[t]{2}{*}{ EGFRvIII } & {$[165]$} & I & $\begin{array}{l}\text { One intravenous dose } 1.75 \times 10^{8}-5 \times 10^{8} \\
\text { CAR T cells }\end{array}$ & MOS 8 months & NCT02209376 \\
\hline & [198] & $\mathrm{I} / \mathrm{II}$ & $\begin{array}{l}\text { Two intravenous doses } 6.3 \times 10^{6} \text { to } 2.6 \times 10^{10} \\
\text { CAR T cells per infusion with an interval } \\
\text { of } 2 \mathrm{~h}\end{array}$ & MOS 6.9 months MPFS 1.3 months & NCT01454596 \\
\hline \multirow[t]{2}{*}{ IL13R $\alpha 2$} & [199] & I & $\begin{array}{l}\text { Intravenous infusions of } 10^{8} \text { CAR T cells on } \\
\text { days } 1,3 \text {, and } 5 \text { for duration of } 2 \text { weeks; } \\
\text { repetition of treatment after } 3 \text { weeks }\end{array}$ & MS after relapse 11 months & NCT00730613 \\
\hline & {$[200]$} & I & $\begin{array}{l}\text { Locoregional injections of } 1 \times 10^{8} \mathrm{CAR} \mathrm{T} \text { cells } \\
\text { and IL- } 2 \text { twice per week for } 2 \text { weeks }\end{array}$ & MOS 19.7 months & NCT01082926 \\
\hline HER2 & [201] & I & $\begin{array}{l}\geq 1 \text { intravenous infusions of } 1 \times 10^{6} / \mathrm{m}^{2}- \\
1 \times 10^{8} / \mathrm{m}^{2} \text { CAR T cells }\end{array}$ & MOS 24.5 months MPFS 3.5 months & NCT01109095 \\
\hline
\end{tabular}

MS median survival, MOS median overall survival, MPFS median progression-free survival

[202]. The current standard therapy for GBM includes maximal surgical resection with consecutive radiotherapy and adjuvant chemotherapy with temozolomide (TMZ). However, despite recent progress in conventional therapeutic approaches with improved overall survival, recurrence is essentially inevitable, indicating that a more aggressive local therapy is required.

Various GBM antigens have been found as a potential target for CAR T cells, from which epidermal growth factor receptor variant III (EGFRvIII), human epidermal growth factor receptor 2 (HER2), and interleukin-13 receptor alpha 2 (IL-13R $\alpha 2$ ) have been clinically verified as effective targets of CAR T cell therapy for GBM [203].

Since the route of administration is an essential determinant in therapeutic success, the question arises which mode of delivery for CAR T cells targeting GBM is the most optimal. Considering that extracranial metastasis is rare in primary brain tumors such as GBM [204], is systemic or locoregional delivery of CAR T cells more advantageous?

As the most common delivery approach for hematological and solid cancers, systemic delivery in form of intravenous (IV) administration exhibits systemic toxicities. Intraventricular (ICV) and/or intratumoral/intracavitary (ICT) administration are locoregional delivery strategies which require the implantation of a catheter delivery device/reservoir placed during surgery. CAR T cells are delivered into the cerebrospinal fluid via the ventricular system in ICV administration, while CAR $\mathrm{T}$ cells are directly administered into the tumor or resected tumor cavity in ICT delivery [177]. Locoregional routes of delivery do not merely lead to decreased risk of systemic toxicities; there is clear evidence that local delivery seems to outperform systemic delivery in terms of efficacy and benefit. For instance, outstanding clinical efficacy was reported in a patient with recurrent multifocal GBM with a regression of all intracranial and spinal tumors after administration of CAR T cells targeting
IL-13R $\alpha 2$ by means of locoregional delivery (ICT and ICV) [174]. This clinical response endured for 7.5 months after the start of CAR T cell therapy. Another clinical trial further shows the limit of systemic administration of CAR T cells targeting EGFRvIII since objective tumor regression could not be induced and delayed progression or prolonged survival in patients with recurrent GBM was not achieved [198]. In contrast, effective antitumor immune response and safety of HER2-specific CAR-modified virus-specific T cells in patients with progressive GBM with no serious adverse events have been observed, with intravenous administration as the route of delivery [201]. However, serious adverse effects following intravenous HER2-specific CAR T cell infusion resulting in pulmonary distress, cardiac arrests, and ultimately death have also been reported in the current literature [156]. This off-tumor toxicity can be attributed to first-pass clearance of HER2-specific CAR T cells in the lung with consecutive release of inflammatory cytokines, causing pulmonary edema and toxicity. A subsequent cytokine storm then leads to multiorgan failure. To prevent such serious adverse effects, a locoregional delivery strategy may be pursued.

Of note, other potential GBM-associated targets for CAR $\mathrm{T}$ cell therapy are currently examined, among others ephrin type A receptor 2 (EphA2) [205, 206], CD 70 [207], the cancer stem cell antigen CD133 [208, 209], chondroitin sulfate proteoglycan 4 (CSPG 4) [210, 211], B7-H3 [212, 213], and podoplanin (PDPN) [214].

A combinatorial approach to enhance antitumor efficacy has been implemented in a human neuroblastoma preclinical model. The combination of CAR T cells with bevacizumab, a recombinant human monoclonal antibody that blocks angiogenesis by inhibiting vascular endothelial growth factor A (VEGF), has shown encouraging results [215]. The theoretical background of the study is that tumor-driven neo-angiogenesis reinforces an immunosuppressive microenvironment 
and influences treatment responses. By administering an additional antiangiogenic drug, tumor vasculature is transiently reprogrammed and bevacizumab-mediated TME remodeling maximizes CAR T cell functions by increasing their tumor infiltration capacity [216].

Apart from the application of CAR T cell therapy for GBM and neuroblastoma, pediatric brain tumors (e.g., medulloblastoma, ependymoma, high-grade gliomas) seem to have the potential to be treated with CAR T cell therapy [217]. A recent study validates intrathecal delivery of CAR T cells targeting EphA2, HER2, and IL-13R $\alpha 2$ as an effective treatment for primary, metastatic, and recurrent medulloblastoma and ependymoma in mouse models [218].

Noteworthily, antigens targeted in GBM to date are either easily downregulated or not particularly tumor-specific, which poses a major problem in the immunotherapy for GBM.

An innovative strategy to overcome tumor heterogeneity has been demonstrated in a recent research article describing the use of chlorotoxin-directed CAR T cells to achieve broader and effective GBM targeting. Although not an antibody-based CAR T cell therapy, this method seems to mediate antitumor activity against established GBM xenografts while simultaneously exhibiting negligible off-target effects. Systemic toxicity was not observed in systemic (intravenous) and regional delivery of chlorotoxin-CAR T cells into healthy and tumor-bearing mice. Results from this study suggest a potent anti-GBM activity of CAR T cells using chlorotoxin as the targeting domain and thereby the potential to reduce antigen escape [219].

Significant challenges in the development of novel therapies are due to certain characteristic features of GBM in contrast to other solid tumors, including biological factors such as the intracranial location, blood-brain barrier, heterogeneity of the tumor, and the unique, immunosuppressive TME [220]. The immunosuppressive TME may suppress the activity and proliferation of CAR T cells by releasing certain inhibitory molecules, soluble factors, and/or cytokines which create physical and metabolic blockades [221]. Intertumor

Table 2 Ongoing clinical trials of CAR T cell therapy in patients with GBM

\begin{tabular}{|c|c|c|c|c|c|}
\hline Target antigen & Study phase & Dosage of CAR T cells & $\begin{array}{l}\text { Enrolment/primary } \\
\text { completion date }\end{array}$ & Sponsor & Clinical trial \\
\hline \multirow[t]{2}{*}{ EGFRvIII } & $\mathrm{I}$ & CART-EGFRvIII + pembrolizumab & 7/December 2020 & University of Pennsylvania & NCT03726515 \\
\hline & $\mathrm{I}$ & $\begin{array}{l}\text { Initial dose of } 2.5 \times 10^{8} \mathrm{CAR} \text { T cells } \\
\text { per intracerebral infusion; dose } \\
\text { escalation in successive cohorts }\end{array}$ & 24/December 2021 & Duke University & NCT03283631 \\
\hline \multirow[t]{2}{*}{ IL13R $\alpha 2$} & $\mathrm{I}$ & $\begin{array}{l}\text { IL13R } \alpha 2 \text {-specific, hinge optimized, } \\
\text { 41BB/truncated CD19-expressing } \\
\text { CAR T cells by locoregional, } \\
\text { intracavitary, or intraventricular } \\
\text { catheter; weekly for } 3 \text { weeks and } \\
\text { additional infusion if eligible }\end{array}$ & 92/January 2021 & City of Hope Medical Center & NCT02206362 \\
\hline & I & $\begin{array}{l}\text { Intravenous infusion of nivolumab } \\
\text { and ipilimumab followed by intra- } \\
\text { ventricular or locoregional infusion } \\
\text { of CAR T cells up to four cycles }\end{array}$ & 60/December 2022 & City of Hope Medical Center & NCT04003649 \\
\hline \multirow[t]{2}{*}{ B7-H3 } & I & $\begin{array}{l}\text { Three locoregional or intracer- } \\
\text { ebroventricular injections of CAR } \\
\text { T cells at two doses between temo- } \\
\text { zolomide cycles }\end{array}$ & 12/May 2022 & $\begin{array}{l}\text { Second Affiliated Hospital, School of } \\
\text { Medicine, Zhejiang University }\end{array}$ & NCT04385173 \\
\hline & $\mathrm{I} / \mathrm{II}$ & $\begin{array}{l}\text { Three locoregional or intracer- } \\
\text { ebroventricular injections of CAR } \\
\text { T cells at two doses between temo- } \\
\text { zolomide cycles }\end{array}$ & 40/June 2024 & $\begin{array}{l}\text { Second Affiliated Hospital of Zhe- } \\
\text { jiang }\end{array}$ & NCT04077866 \\
\hline GD2 & I & $\begin{array}{l}\text { Intravenous injections of } 1 \times 10^{7}- \\
1 \times 10^{8} \mathrm{CAR} \mathrm{T} \text { cells with or with- } \\
\text { out lymphodepletion chemotherapy }\end{array}$ & 34/February 2023 & Baylor College of Medicine & NCT04099797 \\
\hline MMP2 & I & $\begin{array}{l}\text { Three weekly cycles of one or two } \\
\text { CAR T cell infusions }\end{array}$ & 36/February 2023 & City of Hope Medical Center & NCT04214392 \\
\hline CD147 & I & $\begin{array}{l}\text { Intracavity injection of CAR T cells } \\
\text { once per week for } 3 \text { weeks }\end{array}$ & $31 /$ October 2020 & Xijiang Hospital & NCT04045647 \\
\hline Variable & $\mathrm{I}$ & $\begin{array}{l}\text { CAR T cells expressing receptors } \\
\text { specific for EGFRvIII, IL13R } \alpha 2 \text {, } \\
\text { Her2, CD133, EphA2, or GD2 with } \\
\text { or without anti-PDL-1 mAb }\end{array}$ & 100/January 2021 & Xuanwu Hospital & NCT03423992 \\
\hline
\end{tabular}


and intratumor heterogeneities of molecular, genetic, and cellular signatures result in tumor diversity, making GBM more challenging to target with a single antigen. Immune escape and constant immune tolerance also represent limiting factors of CAR T cell therapy.

On the whole, further studies are warranted to evaluate CAR $\mathrm{T}$ cell therapy in patients with brain tumors with respect to its antitumor efficacy, safety profile, and potential combinatorial approaches while simultaneously considering the most important translational challenges.

\section{Conclusions}

In this review, we illustrate the opportunities and challenges of immunotherapies in solid tumors with particular emphasis on GBM and discuss new avenues and novel treatment strategies based on CAR T cells and combination therapy. Tumor-specific redirection of the exquisite lytic capacity of CAR T cell-based therapy has become a promising new treatment modality. Recent advances in research techniques that utilize adoptive cell therapy approaches are expected to bring about crucial developments regarding treatment options for patients suffering from hematologic malignancies and solid tumors, including brain tumors.

GBM thereby shows a particular challenge due to its aggressive nature and highly immunosuppressive TME. CAR T cell therapy has introduced and supported a crucial clinical development for treatment of malignant glioma.

The potential combination of CAR T cells with the investigated antigens, immune checkpoint inhibitors, or inhibitors of angiogenesis present effective strategies to additionally enhance the cytotoxic potential of CAR-engineered immunotherapy against solid tumors and improve their ability to modulate innate and adaptive immune cells in the complex TME. The preferred way to design receptor-targeted therapeutic approaches in neuro-oncology should, among others, include the combined targeting of multiple receptors.

Novel results highlight the potential advantage of locoregional/intraventricular application of CAR T cells compared to systemic application.

Further preclinical and clinical trials are needed to optimize CAR T cell treatment approaches and to harness the antitumor efficacy of CAR T cells combined with adjunct therapies (Table 2).

Author contribution Hyeon Joo Yoo-Idea for the article, screening of relevant publications, data acquisition, analysis and interpretation of data, drafting and revising the manuscript, approving the final draft.
Biyan Nathanael Harapan-Screening of relevant publications, interpretation of data, revising and editing the manuscript, approving the final draft.

Funding Open Access funding enabled and organized by Projekt DEAL.

Data availability Authors can confirm that all relevant data are included in the article. Dataset(s) derived from public resources and made available with the article (references).

Code availability Not applicable.

\section{Declarations}

Conflict of interest The authors declare that they have no conflict of interest.

Ethics approval Not applicable.

Consent to participate Not applicable.

Consent for publication Not applicable.

Open Access This article is licensed under a Creative Commons Attribution 4.0 International License, which permits use, sharing, adaptation, distribution and reproduction in any medium or format, as long as you give appropriate credit to the original author(s) and the source, provide a link to the Creative Commons licence, and indicate if changes were made. The images or other third party material in this article are included in the article's Creative Commons licence, unless indicated otherwise in a credit line to the material. If material is not included in the article's Creative Commons licence and your intended use is not permitted by statutory regulation or exceeds the permitted use, you will need to obtain permission directly from the copyright holder. To view a copy of this licence, visit http://creativecommons.org/licenses/by/4.0/.

\section{References}

1. Rosenberg SA, Packard BS, Aebersold PM, et al. Use of tumor-infiltrating lymphocytes and interleukin-2 in the immunotherapy of patients with metastatic melanoma. A preliminary report. N Engl J Med. 1988;319:1676-80. https://doi.org/10. 1056/NEJM198812223192527.

2. Billingham RE, Brent L, Medawar PB. Quantitative studies on tissue transplantation immunity. II. The origin, strength and duration of actively and adoptively acquired immunity. Proc R Soc Lond B Biol Sci. 1954;143:58-80. https://doi.org/10. 1098/rspb.1954.0054.

3. Mitchison NA. Studies on the immunological response to foreign tumor transplants in the mouse. I. The role of lymph node cells in conferring immunity by adoptive transfer. J Exp Med. 1955;102:157-77. https://doi.org/10.1084/jem.102.2.157.

4. Kolb HJ, Mittermuller J, Clemm C, et al. Donor leukocyte transfusions for treatment of recurrent chronic myelogenous leukemia in marrow transplant patients. Blood. 1990;76:24625. https://doi.org/10.1182/blood.V76.12.2462.2462.

5. Sadelain M, Rivière I, Riddell $\mathrm{S}$. Therapeutic T cell engineering. Nature. 2017;545:423-31. https://doi.org/10.1038/natur e22395. 
6. Hinrichs CS, Rosenberg SA. Exploiting the curative potential of adoptive T-cell therapy for cancer. Immunol Rev. 2014;257:5671. https://doi.org/10.1111/imr.12132.

7. Rosenberg SA, Yannelli JR, Yang JC, et al. Treatment of patients with metastatic melanoma with autologous tumorinfiltrating lymphocytes and interleukin 2. J Natl Cancer Inst. 1994;86:1159-66. https://doi.org/10.1093/jnci/86.15.1159.

8. Rosenberg SA, Yang JC, Sherry RM, et al. Durable complete responses in heavily pretreated patients with metastatic melanoma using T-cell transfer immunotherapy. Clin Cancer Res. 2011;17:4550-7. https://doi.org/10.1158/1078-0432. CCR-11-0116.

9. Garrido F, Ruiz-Cabello F, Cabrera T, et al. Implications for immunosurveillance of altered HLA class I phenotypes in human tumours. Immunol Today. 1997;18:89-95. https://doi.org/10. 1016/s0167-5699(96)10075-x.

10. Rosenberg SA, Aebersold P, Cornetta K, et al. Gene Transfer into humans - immunotherapy of patients with advanced melanoma, using tumor-infiltrating lymphocytes modified by retroviral gene transduction. N Engl J Med. 1990;323:570-8. https://doi.org/10. 1056/NEJM199008303230904.

11. Rischer M, Pscherer S, Duwe S, et al. Human gammadelta $T$ cells as mediators of chimaeric-receptor redirected anti-tumour immunity. Br J Haematol. 2004;126:583-92. https://doi.org/10. 1111/j.1365-2141.2004.05077.x.

12. Turatti F, Figini M, Alberti $P$, et al. Highly efficient redirected anti-tumor activity of human lymphocytes transduced with a completely human chimeric immune receptor. J Gene Med. 2005;7:158-70. https://doi.org/10.1002/jgm.647.

13. Milone MC, Fish JD, Carpenito C, et al. Chimeric receptors containing CD137 signal transduction domains mediate enhanced survival of $\mathrm{T}$ cells and increased antileukemic efficacy in vivo. Mol Ther. 2009;17:1453-64. https://doi.org/10. 1038/mt.2009.83.

14. Varela-Rohena A, Carpenito C, Perez EE, et al. Genetic engineering of T cells for adoptive immunotherapy. Immunol Res. 2008;42:166-81. https://doi.org/10.1007/s12026-008-8057-6.

15. Gyobu H, Tsuji T, Suzuki Y, et al. Generation and targeting of human tumor-specific Tc1 and Th1 cells transduced with a lentivirus containing a chimeric immunoglobulin T-cell receptor. Cancer Res. 2004;64:1490-5. https://doi.org/10.1158/00085472.can-03-2780.

16. Naldini L, Blömer U, Gallay P, et al. In vivo gene delivery and stable transduction of nondividing cells by a lentiviral vector. Science. 1996;272:263-7. https://doi.org/10.1126/science.272. 5259.263.

17. Park JR, Digiusto DL, Slovak M, et al. Adoptive transfer of chimeric antigen receptor re-directed cytolytic T lymphocyte clones in patients with neuroblastoma. Mol Ther. 2007;15:82533. https://doi.org/10.1038/sj.mt.6300104.

18. Till BG, Jensen MC, Wang J, et al. Adoptive immunotherapy for indolent non-Hodgkin lymphoma and mantle cell lymphoma using genetically modified autologous CD20-specific T cells. Blood. 2008;112:2261-71. https://doi.org/10.1182/ blood-2007-12-128843.

19. Geurts AM, Yang Y, Clark KJ, et al. Gene transfer into genomes of human cells by the sleeping beauty transposon system. Mol Ther. 2003;8:108-17. https://doi.org/10.1016/ S1525-0016(03)00099-6.

20. Huang X, Guo H, Kang J, et al. Sleeping beauty transposonmediated engineering of human primary $\mathrm{T}$ cells for therapy of CD19+ lymphoid malignancies. Mol Ther. 2008;16:580-9. https://doi.org/10.1038/sj.mt.6300404.

21. Singh H, Manuri PR, Olivares S, et al. Redirecting specificity of T-cell populations for CD19 using the sleeping beauty system. Cancer Res. 2008;68:2961-71. https://doi.org/10.1158/ 0008-5472.CAN-07-5600.

22. Xue X, Huang X, Nodland SE, et al. Stable gene transfer and expression in cord blood-derived CD34+ hematopoietic stem and progenitor cells by a hyperactive Sleeping Beauty transposon system. Blood. 2009;114:1319-30. https://doi.org/10. 1182/blood-2009-03-210005.

23. Manuri PVR, Wilson MH, Maiti SN, et al. piggyBac transposon/transposase system to generate CD19-specific T cells for the treatment of B-lineage malignancies. Hum Gene Ther. 2010;21:427-37. https://doi.org/10.1089/hum.2009.114.

24. Nakazawa Y, Huye LE, Dotti G, et al. Optimization of the PiggyBac transposon system for the sustained genetic modification of human T lymphocytes. J Immunother. 2009;32:826-36. https://doi.org/10.1097/CJI.0b013e3181ad762b.

25. Hackett PB, Ekker SC, Largaespada DA, et al. Sleeping beauty transposon-mediated gene therapy for prolonged expression. Adv Genet. 2005;54:189-232. https://doi.org/10.1016/S00652660(05)54009-4.

26. Ivics Z, Hackett PB, Plasterk RH, et al. Molecular reconstruction of sleeping beauty, a Tc1-like transposon from fish, and its transposition in human cells. Cell. 1997;91:501-10. https:// doi.org/10.1016/s0092-8674(00)80436-5.

27. Frommolt R, Rohrbach F, Theobald M. Sleeping beauty transposon system-future trend in T-cell-based gene therapies? Future Oncol. 2006;2:345-9. https://doi.org/10.2217/14796694.2.3.345.

28. Geurts AM, Hackett CS, Bell JB, et al. Structure-based prediction of insertion-site preferences of transposons into chromosomes. Nucleic Acids Res. 2006;34:2803-11. https://doi.org/10.1093/ nar/gkl301.

29. Hollis RP, Nightingale SJ, Wang X, et al. Stable gene transfer to human $\mathrm{CD} 34(+)$ hematopoietic cells using the sleeping beauty transposon. Exp Hematol. 2006;34:1333-43. https://doi.org/10. 1016/j.exphem.2006.05.023.

30. Wilber A, Linehan JL, Tian X, et al. Efficient and stable transgene expression in human embryonic stem cells using transposonmediated gene transfer. Stem Cells. 2007;25:2919-27. https:// doi.org/10.1634/stemcells.2007-0026.

31. Izsvák Z, Chuah MK, VandenDriessche T, et al. Efficient stable gene transfer into human cells by the sleeping beauty transposon vectors. Methods. 2009;49:287-97. https://doi.org/10.1016/j. ymeth.2009.07.001.

32. Boissel L, Betancur M, Wels WS, et al. Transfection with mRNA for CD19 specific chimeric antigen receptor restores NK cell mediated killing of CLL cells. Leuk Res. 2009;33:1255-9. https://doi.org/10.1016/j.leukres.2008.11.024.

33. Choi Y, Yuen C, Maiti SN, et al. A high throughput microelectroporation device to introduce a chimeric antigen receptor to redirect the specificity of human T cells. Biomed Microdevices. 2010;12:855-63. https://doi.org/10.1007/s10544-010-9440-3.

34. June $\mathrm{CH}$, Sadelain M. Chimeric antigen receptor therapy. N Engl J Med. 2018;379:64-73. https://doi.org/10.1056/NEJMra1706 169.

35. Sadelain M, Brentjens R, Rivière I. The promise and potential pitfalls of chimeric antigen receptors. Curr Opin Immunol. 2009;21:215-23. https://doi.org/10.1016/j.coi.2009.02.009.

36. Stephan MT, Ponomarev V, Brentjens RJ, et al. T cell-encoded CD80 and 4-1BBL induce auto- and transcostimulation, resulting in potent tumor rejection. Nat Med. 2007;13:1440-9. https:// doi.org/10.1038/nm1676.

37. Scholler J, Brady TL, Binder-Scholl G, et al. Decade-long safety and function of retroviral-modified chimeric antigen receptor T cells. Sci Transl Med. 2012;4:132ra53. https://doi.org/10.1126/ scitranslmed.3003761. 
38. Silverstein AM. Autoimmunity versus horror autotoxicus: the struggle for recognition. Nat Immunol. 2001;2:279-81. https:// doi.org/10.1038/86280.

39. Raval RR, Sharabi AB, Walker AJ, et al. Tumor immunology and cancer immunotherapy: summary of the 2013 SITC primer. J Immunother Cancer. 2014;2:14. https://doi.org/10.1186/ 2051-1426-2-14.

40. June $\mathrm{CH}$, Warshauer JT, Bluestone JA. Is autoimmunity the Achilles' heel of cancer immunotherapy? Nat Med. 2017;23:5407. https://doi.org/10.1038/nm.4321.

41. Park TS, Rosenberg SA, Morgan RA. Treating cancer with genetically engineered T cells. Trends Biotechnol. 2011;29:550-7. https://doi.org/10.1016/j.tibtech.2011.04.009.

42. Johnson LA, June CH. Driving gene-engineered T cell immunotherapy of cancer. Cell Res. 2017;27:38-58. https://doi.org/10. 1038/cr.2016.154.

43. Davenport AJ, Jenkins MR, Cross RS, et al. CAR-T Cells inflict sequential killing of multiple tumor target cells. Cancer Immunol Res. 2015;3:483. https://doi.org/10.1158/2326-6066. CIR-15-0048.

44. Jackson HJ, Rafiq S, Brentjens RJ. Driving CAR T-cells forward. Nat Rev Clin Oncol. 2016;13:370-83. https://doi.org/10.1038/ nrclinonc.2016.36.

45. Sadelain M. CAR therapy: the CD19 paradigm. J Clin Invest. 2015;125:3392-400. https://doi.org/10.1172/JCI80010.

46. Kuwana Y, Asakura Y, Utsunomiya N, et al. Expression of chimeric receptor composed of immunoglobulin-derived $\mathrm{V}$ regions and $\mathrm{T}$-cell receptor-derived $\mathrm{C}$ regions. Biochem Biophys Res Commun. 1987;149:960-8. https://doi.org/10.1016/0006291x(87)90502-x.

47. Gross G, Waks T, Eshhar Z. Expression of immunoglobulin$\mathrm{T}$-cell receptor chimeric molecules as functional receptors with antibody-type specificity. Proc Natl Acad Sci U S A. 1989;86:10024-8. https://doi.org/10.1073/pnas.86.24.10024.

48. Eshhar Z, Waks T, Gross G, et al. Specific activation and targeting of cytotoxic lymphocytes through chimeric single chains consisting of antibody-binding domains and the gamma or zeta subunits of the immunoglobulin and T-cell receptors. Proc Natl Acad Sci U S A. 1993;90:720-4. https://doi.org/10.1073/pnas. 90.2.720.

49. Maher J, Brentjens RJ, Gunset G, et al. Human T-lymphocyte cytotoxicity and proliferation directed by a single chimeric TCRzeta /CD28 receptor. Nat Biotechnol. 2002;20:70-5. https:// doi.org/10.1038/nbt0102-70.

50. Jena B, Dotti G, Cooper LJN. Redirecting T-cell specificity by introducing a tumor-specific chimeric antigen receptor. Blood. 2010;116:1035-44. https://doi.org/10.1182/ blood-2010-01-043737.

51. Zhang H, Snyder KM, Suhoski MM, et al. 4-1BB is superior to $\mathrm{CD} 28$ costimulation for generating $\mathrm{CD} 8+$ cytotoxic lymphocytes for adoptive immunotherapy. J Immunol. 2007;179:4910-8. https://doi.org/10.4049/jimmunol.179.7.4910.

52. Golovina TN, Mikheeva T, Suhoski MM, et al. CD28 costimulation is essential for human $\mathrm{T}$ regulatory expansion and function. J Immunol. 2008;181:2855-68. https://doi.org/10.4049/jimmu nol.181.4.2855.

53. Guedan S, Posey AD, Shaw C, et al. Enhancing CAR T cell persistence through ICOS and 4-1BB costimulation. JCI Insight. 2018;3(1):e96976. https://doi.org/10.1172/jci.insight.96976.

54. Zhang H, Merchant MS, Chua KS, et al. Tumor expression of 4-1BB ligand sustains tumor lytic T cells. Cancer Biol Ther. 2003;2:579-86. https://doi.org/10.4161/cbt.2.5.545.

55. Song D-G, Ye Q, Carpenito C, et al. In vivo persistence, tumor localization, and antitumor activity of CAR-engineered T cells is enhanced by costimulatory signaling through CD137 (4-1BB).
Cancer Res. 2011;71:4617-27. https://doi.org/10.1158/00085472.CAN-11-0422.

56. Rafiq S, Hackett CS, Brentjens RJ. Engineering strategies to overcome the current roadblocks in CAR T cell therapy. Nat Rev Clin Oncol. 2020;17:147-67. https://doi.org/10.1038/ s41571-019-0297-y.

57. Guedan S, Calderon H, Posey AD, JR, et al. Engineering and Design of chimeric antigen receptors. Mol Ther Methods Clin Dev. 2019;12:145-56. https://doi.org/10.1016/j.omtm.2018.12. 009.

58. Brocker T, Peter A, Traunecker A, et al. New simplified molecular design for functional $\mathrm{T}$ cell receptor. Eur J Immunol. 1993;23:1435-9. https://doi.org/10.1002/eji.1830230705.

59. Guest RD, Hawkins RE, Kirillova N, et al. The role of extracellular spacer regions in the optimal design of chimeric immune receptors: evaluation of four different scFvs and antigens. J Immunother. 2005;28:203-11. https://doi.org/10.1097/01.cji. 0000161397.96582.59.

60. James SE, Greenberg PD, Jensen MC, et al. Antigen sensitivity of CD22-specific chimeric TCR is modulated by target epitope distance from the cell membrane. J Immunol. 2008;180:7028-38. https://doi.org/10.4049/jimmunol.180.10.7028.

61. Watanabe N, Bajgain P, Sukumaran S, et al. Fine-tuning the CAR spacer improves T-cell potency. Oncoimmunology. 2016;5: e1253656. https://doi.org/10.1080/2162402X.2016.1253656.

62. Hudecek M, Sommermeyer D, Kosasih PL, et al. The nonsignaling extracellular spacer domain of chimeric antigen receptors is decisive for in vivo antitumor activity. Cancer Immunol Res. 2015;3:125-35. https://doi.org/10.1158/2326-6066.CIR-14-0127.

63. Oei VYS, Siernicka M, Graczyk-Jarzynka A, et al. Intrinsic functional potential of NK-cell subsets constrains retargeting driven by chimeric antigen receptors. Cancer Immunol Res. 2018;6:467-80. https://doi.org/10.1158/2326-6066.CIR-17-0207.

64. Alabanza L, Pegues M, Geldres C, et al. Function of novel antiCD19 chimeric antigen receptors with human variable regions is affected by hinge and transmembrane domains. Mol Ther. 2017;25:2452-65. https://doi.org/10.1016/j.ymthe.2017.07.013.

65. Bridgeman JS, Hawkins RE, Bagley S, et al. The optimal antigen response of chimeric antigen receptors harboring the CD3zeta transmembrane domain is dependent upon incorporation of the receptor into the endogenous TCR/CD3 complex. J Immunol. 2010;184:6938-49. https://doi.org/10.4049/jimmunol.0901766.

66. Brocker T. Chimeric Fv-zeta or Fv-epsilon receptors are not sufficient to induce activation or cytokine production in peripheral T cells. Blood. 2000;96:1999-2001.

67. Brocker T, Karjalainen K. Signals through T cell receptor-zeta chain alone are insufficient to prime resting T lymphocytes. J Exp Med. 1995;181:1653-9. https://doi.org/10.1084/jem.181.5.1653.

68. Kershaw MH, Westwood JA, Parker LL, et al. A phase I study on adoptive immunotherapy using gene-modified $\mathrm{T}$ cells for ovarian cancer. Clin Cancer Res. 2006;12:6106-15. https://doi.org/10. 1158/1078-0432.CCR-06-1183.

69. Pule MA, Savoldo B, Myers GD, et al. Virus-specific T cells engineered to coexpress tumor-specific receptors: persistence and antitumor activity in individuals with neuroblastoma. Nat Med. 2008;14:1264-70. https://doi.org/10.1038/nm.1882.

70. Karlsson H, Svensson E, Gigg C, et al. Evaluation of intracellular signaling downstream chimeric antigen receptors. PLoS ONE. 2015;10: e0144787. https://doi.org/10.1371/journal.pone.01447 87.

71. Sadelain M, Brentjens R, Rivière I. The basic principles of chimeric antigen receptor design. Cancer Discov. 2013;3:388-98. https://doi.org/10.1158/2159-8290.CD-12-0548.

72. Krause A, Guo HF, Latouche JB, et al. Antigen-dependent CD28 signaling selectively enhances survival and proliferation 
in genetically modified activated human primary $\mathrm{T}$ lymphocytes. J Exp Med. 1998;188:619-26. https://doi.org/10.1084/jem.188.4. 619.

73. Song D-G, Ye Q, Poussin M, et al. CD27 costimulation augments the survival and antitumor activity of redirected human $\mathrm{T}$ cells in vivo. Blood. 2012;119:696-706. https://doi.org/10.1182/ blood-2011-03-344275.

74. Loskog A, Giandomenico V, Rossig C, et al. Addition of the CD28 signaling domain to chimeric T-cell receptors enhances chimeric T-cell resistance to $\mathrm{T}$ regulatory cells. Leukemia. 2006;20:1819-28. https://doi.org/10.1038/sj.leu.2404366.

75. Savoldo B, Ramos CA, Liu E, et al. CD28 costimulation improves expansion and persistence of chimeric antigen receptor-modified T cells in lymphoma patients. J Clin Invest. 2011;121:1822-6. https://doi.org/10.1172/JCI46110.

76. Pulè MA, Straathof KC, Dotti G, et al. A chimeric T cell antigen receptor that augments cytokine release and supports clonal expansion of primary human T cells. Mol Ther. 2005;12:933-41. https://doi.org/10.1016/j.ymthe.2005.04.016.

77. Porter DL, Levine BL, Kalos M, et al. Chimeric antigen receptormodified T cells in chronic lymphoid leukemia. N Engl J Med. 2011;365:725-33. https://doi.org/10.1056/NEJMoa1103849.

78. Long AH, Haso WM, Shern JF, et al. 4-1BB costimulation ameliorates $\mathrm{T}$ cell exhaustion induced by tonic signaling of chimeric antigen receptors. Nat Med. 2015;21:581-90. https://doi.org/10. 1038/nm.3838.

79. Dotti G, Gottschalk S, Savoldo B, et al. Design and development of therapies using chimeric antigen receptor-expressing T cells. Immunol Rev. 2014;257:107-26. https://doi.org/10. 1111/imr.12131.

80. Enblad G, Karlsson H, Gammelgård G, et al. A phase I/IIa trial using CD19-targeted third-generation CAR T cells for lymphoma and leukemia. Clin Cancer Res. 2018;24:6185-94. https://doi.org/10.1158/1078-0432.CCR-18-0426.

81. Salter AI, Ivey RG, Kennedy JJ, et al. Phosphoproteomic analysis of chimeric antigen receptor signaling reveals kinetic and quantitative differences that affect cell function. Sci Signal. 2018;11(544):eaat6753. https://doi.org/10.1126/scisignal.aat67 53.

82. U.S. Food \& Drug Administration (2017) FDA approves axicabtagene ciloleucel for large B- cell lymphoma

83. U.S. Food \& Drug Administration (2017) FDA approves tisagenlecleucel for B- cell ALL and tocilizumab for cytokine release syndrome

84. Neelapu SS, Tummala S, Kebriaei P, et al. Chimeric antigen receptor T-cell therapy - assessment and management of toxicities. Nat Rev Clin Oncol. 2018;15:47-62. https://doi.org/10. 1038/nrclinonc.2017.148.

85. Park JH, Rivière I, Gonen M, et al. Long-term follow-up of CD19 CAR therapy in acute lymphoblastic leukemia. N Engl J Med. 2018;378:449-59. https://doi.org/10.1056/NEJMoa1709 919.

86. Maude SL, Laetsch TW, Buechner J, et al. Tisagenlecleucel in children and young adults with B-cell lymphoblastic leukemia. N Engl J Med. 2018;378:439-48. https://doi.org/10.1056/NEJMo a1709866.

87. Schuster SJ, Svoboda J, Chong EA, et al. Chimeric antigen receptor T cells in refractory B-cell lymphomas. N Engl J Med. 2017;377:2545-54. https://doi.org/10.1056/NEJMoa1708566.

88. Neelapu SS, Locke FL, Bartlett NL, et al. Axicabtagene ciloleucel CAR T-cell therapy in refractory large B-cell lymphoma. N Engl J Med. 2017;377:2531-44. https://doi.org/10.1056/NEJMo a1707447.

89. Brentjens RJ, Davila ML, Riviere I, et al. CD19-targeted $\mathrm{T}$ cells rapidly induce molecular remissions in adults with chemotherapy-refractory acute lymphoblastic leukemia. Sci Transl Med. 2013;5:177ra38. https://doi.org/10.1126/scitranslm ed.3005930.

90. Grupp SA, Kalos M, Barrett D, et al. Chimeric antigen receptor-modified T cells for acute lymphoid leukemia. N Engl J Med. 2013;368:1509-18. https://doi.org/10.1056/NEJMoa1215134.

91. Hombach AA, Heiders J, Foppe M, et al. OX40 costimulation by a chimeric antigen receptor abrogates CD28 and IL-2 induced IL-10 secretion by redirected CD4(+) T cells. Oncoimmunology. 2012;1:458-66. https://doi.org/10.4161/onci.19855.

92. Brentjens RJ, Santos E, Nikhamin Y, et al. Genetically targeted $\mathrm{T}$ cells eradicate systemic acute lymphoblastic leukemia xenografts. Clin Cancer Res. 2007;13:5426-35. https://doi.org/10. 1158/1078-0432.CCR-07-0674.

93. Raje N, Berdeja J, Lin Y, et al. Anti-BCMA CAR T-cell therapy bb2121 in relapsed or refractory multiple myeloma. N Engl J Med. 2019;380:1726-37. https://doi.org/10.1056/NEJMoa1817 226.

94. Brudno JN, Kochenderfer JN. Chimeric antigen receptor T-cell therapies for lymphoma. Nat Rev Clin Oncol. 2018;15:31-46. https://doi.org/10.1038/nrclinonc.2017.128.

95. LeBien TW, Tedder TF. B lymphocytes: how they develop and function. Blood. 2008;112:1570-80. https://doi.org/10.1182/ blood-2008-02-078071.

96. Brentjens RJ, Latouche J-B, Santos E, et al. Eradication of systemic B-cell tumors by genetically targeted human T lymphocytes co-stimulated by CD80 and interleukin-15. Nat Med. 2003;9:279-86. https://doi.org/10.1038/nm827.

97. Santomasso B, Bachier C, Westin J, et al. The other side of CAR T-cell therapy: cytokine release syndrome, neurologic toxicity, and financial burden. Am Soc Clin Oncol Educ Book. 2019;39:433-44. https://doi.org/10.1200/EDBK_238691.

98. Depil S, Duchateau P, Grupp SA, et al. 'Off-the-shelf' allogeneic CAR T cells: development and challenges. Nat Rev Drug Discov. 2020;19:185-99. https://doi.org/10.1038/s41573-019-0051-2.

99. Linette GP, Stadtmauer EA, Maus MV, et al. Cardiovascular toxicity and titin cross-reactivity of affinity-enhanced $\mathrm{T}$ cells in myeloma and melanoma. Blood. 2013;122:863-71. https://doi. org/10.1182/blood-2013-03-490565.

100. Sun S, Hao H, Yang G, et al. Immunotherapy with CAR-modified T cells: toxicities and overcoming strategies. J Immunol Res. 2018;2018:2386187. https://doi.org/10.1155/2018/2386187.

101. Hombach A, Hombach AA, Abken H. Adoptive immunotherapy with genetically engineered T cells: modification of the IgG1 Fc "spacer" domain in the extracellular moiety of chimeric antigen receptors avoids "off-target" activation and unintended initiation of an innate immune response. Gene Ther. 2010;17:1206-13. https://doi.org/10.1038/gt.2010.91.

102. Castellarin M, Sands C, Da T, et al. A rational mouse model to detect on-target, off-tumor CAR T cell toxicity. JCI Insight. 2020;5(14):e136012. https://doi.org/10.1172/jci.insight.136012.

103. Lee DW, Gardner R, Porter DL, et al. Current concepts in the diagnosis and management of cytokine release syndrome. Blood. 2014;124:188-95. https://doi.org/10.1182/ blood-2014-05-552729.

104. Lee DW, Santomasso BD, Locke FL, et al. ASTCT consensus grading for cytokine release syndrome and neurologic toxicity associated with immune effector cells. Biol Blood Marrow Transplant. 2019;25:625-38. https://doi.org/10.1016/j.bbmt.2018.12. 758.

105. Harapan BN, Yoo HJ. Neurological symptoms, manifestations, and complications associated with severe acute respiratory syndrome coronavirus 2 (SARS-CoV-2) and coronavirus disease 19 (COVID-19). J Neurol. 2021. https://doi.org/10.1007/ s00415-021-10406-y. 
106. Maude SL, Frey N, Shaw PA, et al. Chimeric antigen receptor $\mathrm{t}$ cells for sustained remissions in leukemia. N Engl J Med. 2014;371:1507-17. https://doi.org/10.1056/NEJMoa1407222.

107. Davila ML, Riviere I, Wang X et al. (2014) Efficacy and toxicity management of $19-28 \mathrm{z}$ CAR T cell therapy in B cell acute lymphoblastic leukemia. Sci Transl Med 6:224ra25. https://doi. org/10.1126/scitranslmed.3008226

108. Mikkilineni L, Kochenderfer JN. CAR T cell therapies for patients with multiple myeloma. Nat Rev Clin Oncol. 2021;18:71-84. https://doi.org/10.1038/s41571-020-0427-6.

109. Teachey DT, Lacey SF, Shaw PA, et al. Identification of predictive biomarkers for cytokine release syndrome after chimeric antigen receptor T-cell therapy for acute lymphoblastic leukemia. Cancer Discov. 2016;6:664-79. https://doi.org/10.1158/21598290.CD-16-0040.

110. Porter DL, Hwang W-T, Frey NV, et al. Chimeric antigen receptor $\mathrm{T}$ cells persist and induce sustained remissions in relapsed refractory chronic lymphocytic leukemia. Sci Transl Med. 2015;7:303ra139. https://doi.org/10.1126/scitranslmed.aac5415.

111. Sheth VS, Gauthier J. Taming the beast: CRS and ICANS after CAR T-cell therapy for ALL. Bone Marrow Transplant. 2021;56:552-66. https://doi.org/10.1038/s41409-020-01134-4.

112. Siegler EL, Kenderian SS. Neurotoxicity and cytokine release syndrome after chimeric antigen receptor $\mathrm{T}$ cell therapy: insights into mechanisms and novel therapies. Front Immunol. 2020;11:1973. https://doi.org/10.3389/fimmu.2020.01973.

113. Topp MS, Gökbuget N, Stein AS, et al. Safety and activity of blinatumomab for adult patients with relapsed or refractory B-precursor acute lymphoblastic leukaemia: a multicentre, single-arm, phase 2 study. Lancet Oncol. 2015;16:57-66. https://doi.org/10. 1016/S1470-2045(14)71170-2.

114. Santomasso BD, Park JH, Salloum D, et al. Clinical and biological correlates of neurotoxicity associated with CAR T-cell therapy in patients with B-cell acute lymphoblastic leukemia. Cancer Discov. 2018;8:958-71. https://doi.org/10.1158/21598290.CD-17-1319.

115. Gust J, Hay KA, Hanafi L-A, et al. Endothelial activation and blood-brain barrier disruption in neurotoxicity after adoptive immunotherapy with CD19 CAR-T cells. Cancer Discov. 2017;7:1404-19. https://doi.org/10.1158/2159-8290. CD-17-0698.

116. Han X, Wang Y, Wei J, et al. Multi-antigen-targeted chimeric antigen receptor $\mathrm{T}$ cells for cancer therapy. J Hematol Oncol. 2019;12:128. https://doi.org/10.1186/s13045-019-0813-7.

117. Grada Z, Hegde M, Byrd T, et al. TanCAR: a novel bispecific chimeric antigen receptor for cancer immunotherapy. Mol Ther Nucleic Acids. 2013;2: e105. https://doi.org/10.1038/mtna.2013. 32.

118. Ruella M, Barrett DM, Kenderian SS, et al. Dual CD19 and CD123 targeting prevents antigen-loss relapses after CD19directed immunotherapies. J Clin Invest. 2016;126:3814-26. https://doi.org/10.1172/JCI87366.

119. Hegde M, Mukherjee M, Grada Z, et al. Tandem CAR T cells targeting HER2 and IL13R $\alpha 2$ mitigate tumor antigen escape. J Clin Invest. 2016;126:3036-52. https://doi.org/10.1172/JCI83 416.

120. Lanitis E, Poussin M, Klattenhoff AW, et al. Chimeric antigen receptor $\mathrm{T}$ Cells with dissociated signaling domains exhibit focused antitumor activity with reduced potential for toxicity in vivo. Cancer Immunol Res. 2013;1:43-53. https://doi.org/10. 1158/2326-6066.CIR-13-0008.

121. Kloss CC, Condomines M, Cartellieri M, et al. Combinatorial antigen recognition with balanced signaling promotes selective tumor eradication by engineered T cells. Nat Biotechnol. 2013;31:71-5. https://doi.org/10.1038/nbt.2459.
122. Roybal KT, Rupp LJ, Morsut L, et al. Precision tumor recognition by T cells with combinatorial antigen-sensing circuits. Cell. 2016;164:770-9. https://doi.org/10.1016/j.cell.2016.01.011.

123. Zhao Z, Condomines M, van der Stegen SJC, et al. Structural design of engineered costimulation determines tumor rejection kinetics and persistence of CAR T cells. Cancer Cell. 2015;28:415-28. https://doi.org/10.1016/j.ccell.2015.09.004.

124. Curran KJ, Seinstra BA, Nikhamin Y, et al. Enhancing antitumor efficacy of chimeric antigen receptor T cells through constitutive CD40L expression. Mol Ther. 2015;23:769-78. https://doi.org/ 10.1038/mt.2015.4.

125. Wu C-Y, Roybal KT, Puchner EM, et al. Remote control of therapeutic $\mathrm{T}$ cells through a small molecule-gated chimeric receptor. Science. 2015;350:aab4077. https://doi.org/10.1126/science. aab4077.

126. Urbanska K, Lanitis E, Poussin M, et al. A universal strategy for adoptive immunotherapy of cancer through use of a novel T-cell antigen receptor. Cancer Res. 2012;72:1844-52. https://doi.org/ 10.1158/0008-5472.CAN-11-3890.

127. Rodgers DT, Mazagova M, Hampton EN, et al. Switch-mediated activation and retargeting of CAR-T cells for B-cell malignancies. Proc Natl Acad Sci U S A. 2016;113:E459-68. https://doi. org/10.1073/pnas.1524155113.

128. Ma JSY, Kim JY, Kazane SA, et al. Versatile strategy for controlling the specificity and activity of engineered T cells. Proc Natl Acad Sci U S A. 2016;113:E450-8. https://doi.org/10.1073/pnas. 1524193113

129. Cho JH, Collins JJ, Wong WW. Universal chimeric antigen receptors for multiplexed and logical control of T cell responses. Cell. 2018;173:1426-1438.e11. https://doi.org/10.1016/j.cell.2018.03. 038.

130. Chmielewski M, Hombach AA, Abken H. Of CARs and TRUCKs: chimeric antigen receptor (CAR) T cells engineered with an inducible cytokine to modulate the tumor stroma. Immunol Rev. 2014;257:83-90. https://doi.org/10.1111/imr.12125.

131. Chmielewski M, Abken H. TRUCKs: the fourth generation of CARs. Expert Opin Biol Ther. 2015;15:1145-54. https://doi.org/ 10.1517/14712598.2015.1046430.

132. Yeku OO, Purdon TJ, Koneru M, et al. Armored CAR T cells enhance antitumor efficacy and overcome the tumor microenvironment. Sci Rep. 2017;7:10541. https://doi.org/10.1038/ s41598-017-10940-8.

133. Koneru M, Purdon TJ, Spriggs D, et al. IL-12 secreting tumortargeted chimeric antigen receptor $\mathrm{T}$ cells eradicate ovarian tumors in vivo. Oncoimmunology. 2015;4: e994446. https://doi. org/10.4161/2162402X.2014.994446.

134. Pegram HJ, Lee JC, Hayman EG, et al. Tumor-targeted T cells modified to secrete IL-12 eradicate systemic tumors without need for prior conditioning. Blood. 2012;119:4133-41. https://doi.org/ 10.1182/blood-2011-12-400044.

135. Krenciute G, Prinzing BL, Yi Z, et al. Transgenic expression of IL15 improves antiglioma activity of IL13R $\alpha 2$-CAR T cells but results in antigen loss variants. Cancer Immunol Res. 2017;5:571-81. https://doi.org/10.1158/2326-6066.CIR-16-0376.

136. Avanzi MP, Yeku O, Li X, et al. Engineered tumor-targeted T cells mediate enhanced anti-tumor efficacy both directly and through activation of the endogenous immune system. Cell Rep. 2018;23:2130-41. https://doi.org/10.1016/j.celrep.2018.04.051.

137. Hu B, Ren J, Luo Y, et al. Augmentation of antitumor immunity by human and mouse CAR T cells secreting IL-18. Cell Rep. 2017;20:3025-33. https://doi.org/10.1016/j.celrep.2017.09.002.

138. Markley JC, Sadelain M. IL-7 and IL-21 are superior to IL-2 and IL-15 in promoting human T cell-mediated rejection of systemic lymphoma in immunodeficient mice. Blood. 2010;115:3508-19. https://doi.org/10.1182/blood-2009-09-241398. 
139. Klebanoff CA, Finkelstein SE, Surman DR, et al. IL-15 enhances the in vivo antitumor activity of tumor-reactive CD8+ T cells. Proc Natl Acad Sci U S A. 2004;101:1969-74. https://doi.org/ 10.1073/pnas.0307298101.

140. Xu Y, Zhang M, Ramos CA, et al. Closely related T-memory stem cells correlate with in vivo expansion of CAR.CD19-T cells and are preserved by IL-7 and IL-15. Blood. 2014;123:3750-9. https://doi.org/10.1182/blood-2014-01-552174.

141. Mlecnik B, Bindea G, Angell HK, et al. Functional network pipeline reveals genetic determinants associated with in situ lymphocyte proliferation and survival of cancer patients. Sci Transl Med. 2014;6:228ra37. https://doi.org/10.1126/scitranslmed.3007240.

142. Chmielewski M, Kopecky C, Hombach AA, et al. IL-12 release by engineered $\mathrm{T}$ cells expressing chimeric antigen receptors can effectively Muster an antigen-independent macrophage response on tumor cells that have shut down tumor antigen expression. Cancer Res. 2011;71:5697-706. https://doi.org/10.1158/00085472.CAN-11-0103.

143. Zhang L, Feldman SA, Zheng Z, et al. Evaluation of $\gamma$-retroviral vectors that mediate the inducible expression of IL-12 for clinical application. J Immunother. 2012;35:430-9. https://doi.org/ 10.1097/CJI.0b013e31825898e8.

144. Zhang L, Morgan RA, Beane JD, et al. Tumor-infiltrating lymphocytes genetically engineered with an inducible gene encoding interleukin-12 for the immunotherapy of metastatic melanoma. Clin Cancer Res. 2015;21:2278-88. https://doi.org/10.1158/ 1078-0432.CCR-14-2085.

145. Fedorov VD, Themeli M, Sadelain M. PD-1-and CTLA-4-based inhibitory chimeric antigen receptors (iCARs) divert off-target immunotherapy responses. Sci Transl Med. 2013;5:215ra172. https://doi.org/10.1126/scitranslmed.3006597.

146. Yu S, Yi M, Qin S, et al. Next generation chimeric antigen receptor T cells: safety strategies to overcome toxicity. Mol Cancer. 2019;18:125. https://doi.org/10.1186/s12943-019-1057-4.

147. Burger MC, Zhang C, Harter PN, et al. CAR-Engineered NK cells for the treatment of glioblastoma: turning innate effectors into precision tools for cancer immunotherapy. Front Immunol. 2019;10:2683. https://doi.org/10.3389/fimmu.2019.02683.

148. Glienke W, Esser R, Priesner C, et al. Advantages and applications of CAR-expressing natural killer cells. Front Pharmacol. 2015;6:21. https://doi.org/10.3389/fphar.2015.00021.

149. Morgan MA, Büning H, Sauer M, et al. Use of cell and genome modification technologies to generate improved "off-the-shelf" CAR T and CAR NK cells. Front Immunol. 2020;11:1965. https://doi.org/10.3389/fimmu.2020.01965.

150. Ma S, Li X, Wang X, et al. Current progress in CAR-T cell therapy for solid tumors. Int J Biol Sci. 2019;15:2548-60. https://doi. org/10.7150/ijbs.34213.

151. Suarez ER, Chang DK, Sun J, et al. Chimeric antigen receptor $\mathrm{T}$ cells secreting anti-PD-L1 antibodies more effectively regress renal cell carcinoma in a humanized mouse model. Oncotarget. 2016;7:34341-55. https://doi.org/10.18632/oncotarget.9114.

152. Zhu X, Cai H, Zhao L, et al. CAR-T cell therapy in ovarian cancer: from the bench to the bedside. Oncotarget. 2017;8:6460721. https://doi.org/10.18632/oncotarget.19929.

153. Mitwasi N, Feldmann A, Bergmann R, et al. Development of novel target modules for retargeting of UniCAR T cells to GD2 positive tumor cells. Oncotarget. 2017;8:108584-603. https:// doi.org/10.18632/oncotarget.21017.

154. Feldmann A, Arndt C, Bergmann R, et al. Retargeting of T lymphocytes to PSCA- or PSMA positive prostate cancer cells using the novel modular chimeric antigen receptor platform technology "UniCAR." Oncotarget. 2017;8:31368-85. https://doi.org/ 10.18632/oncotarget.15572.

155. Loureiro LR, Feldmann A, Bergmann R, et al. Development of a novel target module redirecting UniCAR T cells to Sialyl
Tn-expressing tumor cells. Blood Cancer J. 2018;8:81. https:// doi.org/10.1038/s41408-018-0113-4.

156. Morgan RA, Yang JC, Kitano M, et al. Case report of a serious adverse event following the administration of $\mathrm{T}$ cells transduced with a chimeric antigen receptor recognizing ERBB2. Mol Ther. 2010;18:843-51. https://doi.org/10.1038/mt.2010.24.

157. Richman SA, Nunez-Cruz S, Moghimi B, et al. High-affinity GD2-specific CAR T cells induce fatal encephalitis in a preclinical neuroblastoma model. Cancer Immunol Res. 2018;6:36-46. https://doi.org/10.1158/2326-6066.CIR-17-0211.

158. Magee MS, Abraham TS, Baybutt TR, et al. Human GUCY2Ctargeted chimeric antigen receptor (CAR)-expressing $\mathrm{T}$ cells eliminate colorectal cancer metastases. Cancer Immunol Res. 2018;6:509-16. https://doi.org/10.1158/2326-6066.CIR-16-0362.

159. Bräunlein E, Krackhardt AM. Identification and characterization of neoantigens as well as respective immune responses in cancer patients. Front Immunol. 2017;8:1702. https://doi.org/10.3389/ fimmu.2017.01702.

160. Schubert M-L, Hoffmann J-M, Dreger P, et al. Chimeric antigen receptor transduced $\mathrm{T}$ cells: tuning up for the next generation. Int J Cancer. 2018;142:1738-47. https://doi.org/10.1002/ijc.31147.

161. Junttila MR, de Sauvage FJ. Influence of tumour microenvironment heterogeneity on therapeutic response. Nature. 2013;501:346-54. https://doi.org/10.1038/nature12626.

162. Croci DO, Zacarías Fluck MF, Rico MJ, et al. Dynamic crosstalk between tumor and immune cells in orchestrating the immunosuppressive network at the tumor microenvironment. Cancer Immunol Immunother. 2007;56:1687-700. https://doi.org/10. 1007/s00262-007-0343-y.

163. Ruella M, Maus MV. Catch me if you can: leukemia escape after CD19-directed T cell immunotherapies. Comput Struct Biotechnol J. 2016;14:357-62. https://doi.org/10.1016/j.csbj.2016.09. 003.

164. Sotillo E, Barrett DM, Black KL, et al. Convergence of acquired mutations and alternative splicing of CD19 enables resistance to CART-19 immunotherapy. Cancer Discov. 2015;5:1282-95. https://doi.org/10.1158/2159-8290.CD-15-1020.

165. O'Rourke DM, Nasrallah MP, Desai A, et al. A single dose of peripherally infused EGFRvIII-directed CAR T cells mediates antigen loss and induces adaptive resistance in patients with recurrent glioblastoma. Sci Transl Med. 2017;9(399):eaaa0984. https://doi.org/10.1126/scitranslmed.aaa0984.

166. Srivastava S, Riddell SR. Chimeric antigen receptor $\mathrm{T}$ cell therapy: challenges to bench-to-bedside efficacy. J Immunol. 2018;200:459-68. https://doi.org/10.4049/jimmunol.1701155.

167. Kailayangiri S, Altvater B, Wiebel M, et al. Overcoming heterogeneity of antigen expression for effective CAR T cell targeting of cancers. Cancers (Basel). 2020;12(5):1075. https://doi.org/10. 3390/cancers12051075.

168. Corbière V, Chapiro J, Stroobant V, et al. Antigen spreading contributes to MAGE vaccination-induced regression of melanoma metastases. Cancer Res. 2011;71:1253-62. https://doi.org/10. 1158/0008-5472.CAN-10-2693.

169. Tosch C, Bastien B, Barraud L, et al. Viral based vaccine TG4010 induces broadening of specific immune response and improves outcome in advanced NSCLC. J Immunother Cancer. 2017;5:70. https://doi.org/10.1186/s40425-017-0274-x.

170. Beatty GL, Haas AR, Maus MV, et al. Mesothelin-specific chimeric antigen receptor mRNA-engineered $\mathrm{T}$ cells induce antitumor activity in solid malignancies. Cancer Immunol Res. 2014;2:112-20. https://doi.org/10.1158/2326-6066.CIR-13-0170.

171. Evans RA, Diamond MS, Rech AJ, et al. Lack of immunoediting in murine pancreatic cancer reversed with neoantigen. JCI Insight. 2016;1(14):e88328. https://doi.org/10.1172/jci.insight. 88328. 
172. Leen AM, Sukumaran S, Watanabe N, et al. Reversal of tumor immune inhibition using a chimeric cytokine receptor. Mol Ther. 2014;22:1211-20. https://doi.org/10.1038/mt.2014.47.

173. Wing A, Fajardo CA, Posey AD, JR, , et al. Improving CART-cell therapy of solid tumors with oncolytic virus-driven production of a bispecific T-cell engager. Cancer Immunol Res. 2018;6:60516. https://doi.org/10.1158/2326-6066.CIR-17-0314.

174. Brown CE, Alizadeh D, Starr R, et al. Regression of glioblastoma after chimeric antigen receptor T-cell therapy. N Engl J Med. 2016;375:2561-9. https://doi.org/10.1056/NEJMoa1610497.

175. Tchou J, Zhao Y, Levine BL, et al. Safety and efficacy of intratumoral injections of chimeric antigen receptor (CAR) $\mathrm{T}$ cells in metastatic breast cancer. Cancer Immunol Res. 2017;5:1152-61. https://doi.org/10.1158/2326-6066.CIR-17-0189.

176. Katz SC, Burga RA, McCormack E, et al. Phase I Hepatic immunotherapy for metastases study of intra-arterial chimeric antigen receptor-modified T-cell therapy for CEA+ liver metastases. Clin Cancer Res. 2015;21:3149-59. https://doi.org/10.1158/10780432.CCR-14-1421.

177. Sridhar P, Petrocca F. Regional delivery of chimeric antigen receptor (CAR) T-cells for cancer therapy. Cancers (Basel). 2017;9(7):92. https://doi.org/10.3390/cancers9070092.

178. Nagarsheth N, Wicha MS, Zou W. Chemokines in the cancer microenvironment and their relevance in cancer immunotherapy. Nat Rev Immunol. 2017;17:559-72. https://doi.org/10.1038/nri. 2017.49.

179. Craddock JA, an Lu, Bear A, , et al. Enhanced tumor trafficking of GD2 chimeric antigen receptor T cells by expression of the chemokine receptor CCR2b. J Immunother. 2010;33:780-8. https://doi.org/10.1097/CJI.0b013e3181ee6675.

180. Moon EK, Carpenito C, Sun J, et al. Expression of a functional CCR2 receptor enhances tumor localization and tumor eradication by retargeted human $\mathrm{T}$ cells expressing a mesothelin-specific chimeric antibody receptor. Clin Cancer Res. 2011;17:4719-30. https://doi.org/10.1158/1078-0432.CCR-11-0351.

181. Di Stasi A, de Angelis B, Rooney CM, et al. T lymphocytes coexpressing CCR4 and a chimeric antigen receptor targeting CD30 have improved homing and antitumor activity in a Hodgkin tumor model. Blood. 2009;113:6392-402. https://doi.org/10. 1182/blood-2009-03-209650.

182. Korman AJ, Peggs KS, Allison JP. Checkpoint blockade in cancer immunotherapy. Adv Immunol. 2006;90:297-339. https:// doi.org/10.1016/S0065-2776(06)90008-X.

183. Rafiq S, Yeku OO, Jackson HJ, et al. Targeted delivery of a PD1-blocking scFv by CAR-T cells enhances anti-tumor efficacy in vivo. Nat Biotechnol. 2018;36:847-56. https://doi.org/10. $1038 /$ nbt. 4195

184. Li S, Siriwon N, Zhang X, et al. Enhanced cancer immunotherapy by chimeric antigen receptor-modified $\mathrm{T}$ cells engineered to secrete checkpoint inhibitors. Clin Cancer Res. 2017;23:698292. https://doi.org/10.1158/1078-0432.CCR-17-0867.

185. Yoon DH, Osborn MJ, Tolar J, et al. Incorporation of immune checkpoint blockade into chimeric antigen receptor $\mathrm{T}$ cells (CAR-Ts): combination or built-In CAR-T. Int J Mol Sci. 2018;19(2):340. https://doi.org/10.3390/ijms19020340.

186. Xu X, Sun Q, Liang X, et al. Mechanisms of relapse after CD19 CAR T-cell therapy for acute lymphoblastic leukemia and its prevention and treatment strategies. Front Immunol. 2019;10:2664. https://doi.org/10.3389/fimmu.2019.02664.

187. Chong EA, Melenhorst JJ, Svoboda J, et al. Phase I/II study of pembrolizumab for progressive diffuse large B cell lymphoma after anti-CD19 directed chimeric antigen receptor modified T cell therapy. Blood. 2017;130:4121. https://doi.org/10.1182/ blood.V130.Suppl_1.4121.4121.
188. Yoo HJ, Liu Y, Wang L, et al. Tumor-specific reactive oxygen species accelerators improve chimeric antigen receptor $\mathrm{T}$ cell therapy in B cell malignancies. Int J Mol Sci. 2019;20(10):2469. https://doi.org/10.3390/ijms20102469.

189. Beavis PA, Henderson MA, Giuffrida L, et al. Targeting the adenosine $2 \mathrm{~A}$ receptor enhances chimeric antigen receptor $\mathrm{T}$ cell efficacy. J Clin Invest. 2017;127:929-41. https://doi.org/10. 1172/JCI89455.

190. Siriwon N, Kim YJ, Siegler E, et al. CAR-T cells surfaceengineered with drug-encapsulated nanoparticles can ameliorate intratumoral T-cell hypofunction. Cancer Immunol Res. 2018;6:812-24. https://doi.org/10.1158/2326-6066.CIR-17-0502.

191. Mohammed S, Sukumaran S, Bajgain P, et al. Improving chimeric antigen receptor-modified $\mathrm{T}$ Cell function by reversing the immunosuppressive tumor microenvironment of pancreatic cancer. Mol Ther. 2017;25:249-58. https://doi.org/10.1016/j. ymthe.2016.10.016.

192. Wilkie S, Burbridge SE, Chiapero-Stanke L, et al. Selective expansion of chimeric antigen receptor-targeted T-cells with potent effector function using interleukin-4. J Biol Chem. 2010;285:25538-44. https://doi.org/10.1074/jbc.M110.127951.

193. Kloss CC, Lee J, Zhang A, et al. Dominant-negative TGF- $\beta$ receptor enhances PSMA-targeted human CAR T cell proliferation and augments prostate cancer eradication. Mol Ther. 2018;26:1855-66. https://doi.org/10.1016/j.ymthe.2018.05.003.

194. Xu X, Gnanaprakasam JNR, Sherman J, et al. A metabolism toolbox for CAR T therapy. Front Oncol. 2019;9:322. https:// doi.org/10.3389/fonc.2019.00322.

195. Hsu PP, Sabatini DM. Cancer cell metabolism: Warburg and beyond. Cell. 2008;134:703-7. https://doi.org/10.1016/j.cell. 2008.08.021.

196. Geiger R, Rieckmann JC, Wolf T, et al. L-Arginine modulates T cell metabolism and enhances survival and anti-tumor activity. Cell. 2016;167:829-842.e13. https://doi.org/10.1016/j.cell.2016. 09.031 .

197. Ando T, Mimura K, Johansson CC, et al. Transduction with the antioxidant enzyme catalase protects human T cells against oxidative stress. J Immunol. 2008;181:8382. https://doi.org/10.4049/ jimmunol.181.12.8382.

198. Goff SL, Morgan RA, Yang JC, et al. Pilot trial of adoptive transfer of chimeric antigen receptor-transduced $\mathrm{T}$ cells targeting EGFRvIII in patients with glioblastoma. J Immunother. 2019;42:126-35. https://doi.org/10.1097/CJI.0000000000 000260 .

199. Brown CE, Starr R, Aguilar B, et al. Clinical development of IL13R $\alpha 2$-targeting CAR T cells for the treatment of glioblastoma. J Immunother Cancer. 2015;3:P114. https://doi.org/10. 1186/2051-1426-3-S2-P114.

200. Keu KV, Witney TH, Yaghoubi S, et al. Reporter gene imaging of targeted T cell immunotherapy in recurrent glioma. Sci Transl Med. 2017;9:eaag2196. https://doi.org/10.1126/scitranslm ed.aag2196

201. Ahmed N, Brawley V, Hegde M, et al. HER2-specific chimeric antigen receptor-modified virus-specific $\mathrm{T}$ cells for progressive glioblastoma: a phase 1 dose-escalation trial. JAMA Oncol. 2017;3:1094-101. https://doi.org/10.1001/jamaoncol.2017.0184.

202. Carlsson SK, Brothers SP, Wahlestedt C. Emerging treatment strategies for glioblastoma multiforme. EMBO Mol Med. 2014;6:1359-70. https://doi.org/10.15252/emmm.201302627.

203. Choi BD, Curry WT, Carter BS, et al. Chimeric antigen receptor T-cell immunotherapy for glioblastoma: practical insights for neurosurgeons. Neurosurg Focus. 2018;44:E13. https://doi.org/ 10.3171/2018.2.FOCUS17788.

204. Liu J, Shen L, Tang G, et al. Multiple extracranial metastases from glioblastoma multiforme: a case report and literature 
review. J Int Med Res. 2020;48:300060520930459. https://doi. org/10.1177/0300060520930459.

205. Chow KKH, Naik S, Kakarla S, et al. T cells redirected to EphA2 for the immunotherapy of glioblastoma. Mol Ther. 2013;21:62937. https://doi.org/10.1038/mt.2012.210.

206. Yi Z, Prinzing BL, Cao F, et al. Optimizing EphA2-CAR T cells for the adoptive immunotherapy of glioma. Mol Ther Methods Clin Dev. 2018;9:70-80. https://doi.org/10.1016/j.omtm.2018. 01.009 .

207. Jin L, Ge H, Long Y, et al. CD70, a novel target of CAR T-cell therapy for gliomas. Neuro Oncol. 2018;20:55-65. https://doi. org/10.1093/neuonc/nox116.

208. Zhu X, Prasad S, Gaedicke S, et al. Patient-derived glioblastoma stem cells are killed by CD133-specific CAR T cells but induce the T cell aging marker CD57. Oncotarget. 2015;6:171-84. https://doi.org/10.18632/oncotarget.2767.

209. Vora P, Venugopal C, Salim SK, et al. The rational development of CD133-targeting immunotherapies for glioblastoma. Cell Stem Cell. 2020;26:832-844.e6. https://doi.org/10.1016/j.stem. 2020.04.008.

210. Pellegatta S, Savoldo B, Di Ianni N, et al. Constitutive and $\mathrm{TNF} \alpha$-inducible expression of chondroitin sulfate proteoglycan 4 in glioblastoma and neurospheres: Implications for CAR-T cell therapy. Sci Transl Med. 2018;10(430):eaao2731. https://doi.org/ 10.1126/scitranslmed.aao2731.

211. Geldres C, Savoldo B, Hoyos V, et al. T lymphocytes redirected against the chondroitin sulfate proteoglycan-4 control the growth of multiple solid tumors both in vitro and in vivo. Clin Cancer Res. 2014;20:962-71. https://doi.org/10.1158/1078-0432. CCR-13-2218.

212. Tang X, Zhao S, Zhang Y, et al. B7-H3 as a novel CAR-T therapeutic target for glioblastoma. Mol Ther Oncolytics. 2019;14:279-87. https://doi.org/10.1016/j.omto.2019.07.002.

213. Nehama D, Di Ianni N, Musio S, et al. B7-H3-redirected chimeric antigen receptor $\mathrm{T}$ cells target glioblastoma and neurospheres. EBioMedicine. 2019;47:33-43. https://doi.org/10. 1016/j.ebiom.2019.08.030.
214. Shiina S, Ohno M, Ohka F, et al. CAR T cells targeting podoplanin reduce orthotopic glioblastomas in mouse brains. Cancer Immunol Res. 2016;4:259-68. https://doi.org/10.1158/23266066.CIR-15-0060.

215. Bocca P, Di Carlo E, Caruana I, et al. Bevacizumab-mediated tumor vasculature remodelling improves tumor infiltration and antitumor efficacy of GD2-CAR T cells in a human neuroblastoma preclinical model. Oncoimmunology. 2017;7: e1378843. https://doi.org/10.1080/2162402X.2017.1378843.

216. Jain RK. Antiangiogenesis strategies revisited: from starving tumors to alleviating hypoxia. Cancer Cell. 2014;26:605-22. https://doi.org/10.1016/j.ccell.2014.10.006.

217. Patterson JD, Henson JC, Breese RO, et al. CAR T cell therapy for pediatric brain tumors. Front Oncol. 2020;10:1582. https:// doi.org/10.3389/fonc.2020.01582.

218. Donovan LK, Delaidelli A, Joseph SK, et al. Locoregional delivery of CAR T cells to the cerebrospinal fluid for treatment of metastatic medulloblastoma and ependymoma. Nat Med. 2020;26:720-31. https://doi.org/10.1038/s41591-020-0827-2.

219. Wang D, Starr R, Chang W-C, et al. Chlorotoxin-directed CAR $\mathrm{T}$ cells for specific and effective targeting of glioblastoma. Sci Transl Med. 2020;12(533):eaaw2672. https://doi.org/10.1126/ scitranslmed.aaw2672.

220. Majc B, Novak M, Jerala NK, et al. Immunotherapy of glioblastoma: current strategies and challenges in tumor model development. Cells. 2021;10(2):265. https://doi.org/10.3390/cells10020 265.

221. Di Cintio F, Dal Bo M, Baboci L, et al. The molecular and microenvironmental landscape of glioblastomas: implications for the novel treatment choices. Front Neurosci. 2020;14: 603647. https://doi.org/10.3389/fnins.2020.603647.

Publisher's note Springer Nature remains neutral with regard to jurisdictional claims in published maps and institutional affiliations. 